\title{
A STUDY OF ENGLISH LISTENING STRATEGIES APPLIED BY ENGLISH NON-MAJORED STUDENTS AT TAY DO UNIVERSITY, VIETNAM
}

\author{
Hanh Thi Dang, \\ Bich Van Au, \\ Hai Thanh Chau ${ }^{\mathrm{i}}$ \\ Tay Do University, \\ Vietnam
}

\begin{abstract}
:
Listening comprehension is one of the important skills for learning a foreign language. Among four basic skills in language leaning, many researchers say that listening skill is applied the most frequently. Therefore, strategies for listening comprehension and the ability to employ them effectively are indispensable in language learning. This paper was an attempt to investigate the listening strategies employed by English non-majored students at Tay Do University. A total of 64 students of two different majors at the university participated in this study to answer a widely used language learning strategy questionnaire. The questionnaire consists of 31 questions including metacognitive strategies, cognitive strategies, social and affective strategies. The data were analyzed by SPSS 11.5 program. The findings indicated that most students applied listening strategies with different degrees and they needed guidance from their instructors. Moreover, the study also presents the relationships among these listening strategies. Finally, the results of this study provide implications for improving the quality of teaching and learning listening skill in the Vietnamese context.
\end{abstract}

Keywords: English listening strategies; listening comprehension; English non-majored students

\section{Introduction}

\subsection{Rationale}

English is considered like the emperor of languages because it is the most widely used all over the world. According to a British Council's statistics (2011), there are about 61.850.000 people using English as their mother tongue and there are more than 1.6 billion people using English as a second language or foreign language. Especially, in the period

i Correspondence: email dthanh@tdu.edu.vn 
of economic integration and globalization, English becomes an essential tool in communication and bridge to link the whole world together. In fact, nowadays there are many international organizations established like the United Nations, NATO, G7 or European Free Trade Association which use English as main language in conferences. English is the main language used by diplomats or politicians from different countries in communicative process. In addition, people all over the world can contact together by internet such as checking mail, discussing online. That is a good way for people to widen knowledge. Imaginably, without English, the whole world might not be as united as it is today. The benefits of English can be seen when Vietnam joined the World Trade Organization (WTO) and opened its market to the world. Learning English has become a basic need for professionals in various fields and for those preparing to join a competitive labor market increasingly. Therefore, mastering English is very necessary for Vietnamese, especially students who are studying in universities. With good knowledge of English, students will have a lot of opportunities to get good jobs or continue their studying abroad.

However, it is not easy to master English. And when mentioning to learning English, students need four main skills to achieve a good communication. They are listening, speaking, reading and writing. Among these skills, listening is appreciated as the most important skill. Guo \& Will $(2006, \mathrm{p} 6)$ said that "listening is an important skill because successful communication depends on not only receiving messages but also decoding them correctly." According to Lu's (2008) study, the results demonstrated that $93.8 \%$ of students considered the listening skill more important than the other three skills. On the other hand, it is probably the most difficult one for students to study. There are a lot of factors that hinder students from listening comprehension.

According to Yan (2006), linguistic factors and non-linguistic factors were two ones which affected learners' listening comprehension. For linguistic factors, they include pronunciation, vocabulary, pattern drills, while psychological, physiological and culture factors are the non-linguistic factors. For example about pronunciation, when people speak English they create a special difference in accent, intonation... It is explained that because they come from many areas of the world, they have particular English accent. So, it influences learners' listening ability. Moreover, most of students studying in Tay Do University think that they are afraid of listening. They find that listening skill is the most difficult skill among skills they studied because they have to identify words, meanings of words and pronunciations of words while listening. All of those reasons hinder their listening comprehension. For presented problems and real situation above, learners need to use listening strategies as a useful tool to help them comprehend, learn and retain information (O'Malley \& Chamot, 1989). With positive reasons above, researcher would like to find out a study to survey whether students at Tay Do University have applied listening strategies in improving listening skill. 


\subsection{Aims and significance of the research}

\subsubsection{Aims of the research}

The study is conducted to investigate if the listening strategies are applied by English non-majored students at Tay Do University in their listening comprehension. Moreover, the study also gives if there is a relationship among these strategies.

\subsubsection{Significance of the research}

Listening skill has been widely taught in most English classes. However, this skill is not still used effectively by learners. This study might provide more insight in this field. Besides, the results from the study will be necessary references for both teachers and learners to evaluate their teaching and learning listening skill in class as well as the application in daily communication.

\subsection{Organization of the research}

This thesis is presented in five chapters including:

- Chapter one is the introduction which deals with the rationale, aims and significance of the research, finally research organization.

- Chapter two is the literature review which includes the listening comprehension, factors affecting EFL learners' English listening comprehension, the importance of learning strategies, listening strategies and previous studies on listening comprehension strategies.

- Chapter three outlines research method consisting of research question and hypotheses, research design, participants, instruments, procedure and data analysis.

- Chapter four expresses the results of questionnaire and gives conclusion for these results.

- Chapter five, the conclusion of the present study including the summary of this research, its implications in teaching and learning English listening skill, its limitations and some suggestions for further research are presented.

\section{Literature review}

In this chapter, researcher will present (1) listening comprehension, (2) Factors affecting EFL learner's English listening comprehension, (3) the importance of learning strategies for language learning, (4) strategies for listening comprehension, (5) previous studies on listening strategies.

\subsection{Listening comprehension}

\subsubsection{Definition of listening comprehension}

Listening is the most common communicative activity in daily life. There are a lot of definitions of listening stated by linguists or experts. Firstly, Purdy (1997) defined listening as "listening is the active and dynamic process of attending, perceiving, interpreting, 
remembering and responding to the expressed (verbal and nonverbal), needs, concerns and information offered by other human beings"(p.8). In the same way, Underwood (1989, p.1) said that "listening is the activity of paying attention to and trying to get meaning from something we hear". From these definitions, it gives some definitions about listening comprehension. Mendelsohn (1994) defined listening comprehension as "the ability to understand the spoken language of native speakers". Similarly, Howatt and Dakin (1974) described listening as the ability to identify and understand what others are saying. And according to these experts, they thought that it was a process including understanding speakers' accent or pronunciation, grammar, vocabulary and meaning comprehension. These four things can be done simultaneously by an able listener. $\mathrm{O}^{\prime}$ Malley, Chamot and Kupper (1989, p.19) offered a more extensive definition that "listening comprehension is an active and conscious process in which the listener construct meaning by using clues from contextual information and from existing knowledge, while relying upon multiple strategy resources to fulfill the task requirement" In brief, listening comprehension is a process that a person consciously receive information, interpret it and respond to the speakers.

\subsubsection{Significance of listening}

Listening is the most frequently used skill in language learning process (Morley, 1999; Scarcella \& Oxford, 1992). However, for last few years, listening skill has been referred to as a skill "taken for granted and overlooked" (Hegde, 2005, p.229). But with social development, human beings have realized how important the listening skill is because listening process will provide the aural input that serves as the basic for language acquisition and influence spoken communication of learners. Wills and Guo (2006) emphasized that "listening is the first language mode that children acquire. It provides the foundation for all aspects of language and cognitive development, and it plays a life-long role in the process of communication". A lot of studies are conducted to illustrate that listening skill is really the most important skill. A study by Feyten (1991) found that most of people spent $45 \%$ of time for listening, 30\% for speaking, $16 \%$ for reading and only $9 \%$ for writing. Bird (1953) had also a similar research surveying on female college students. The results indicated that students allotted $42 \%$ in their total verbal communication time for listening while they took $25 \%$ for speaking, $18 \%$ for writing and only $15 \%$ for reading. The finding was also confirmed by study of Baker, Edwards, Gaines, Gladney, and Holley (1980). The results showed that the portion of verbal communication time spent by college students was $52.5 \%$ on listening, $17.3 \%$ on reading, $16.3 \%$ on speaking, and $13.9 \%$ on writing. Wolvin and Coakley (1988) said that both in and out of classroom, listening consumes more communicative time than other forms of verbal communication. In fact, listening is the most frequently used language skill in classrooms (Ferris, 1998; Murphy, 1991). From above studies, it can be seen that communicative process will not be able to happen in any meaningful way if without listening. 


\subsection{Factors affecting EFL learners' English listening comprehension}

Listening actually plays an important role in learning a language especially ESL or a foreign language. However, if you cannot listen well, maybe you will find it hard to communicate. Especially, those cannot pass their listening examination for instance. Thus, to help students be able to improve their listening skill, it is necessary to find out listening problems which cause difficulties to them. Firstly, Yagang (1994) stated that problems in listening were accompanied with four following factors: the message, the speaker, the listener and the physical setting. For the message, students usually get problems with understanding content and linguistic features. About content, many learners find that it is difficult to listen to a taped message because there are many topics that they are strange to learners. Messages on the radio or recorded on tape cannot be listened to at a slower speed. Even in conversation, it is impossible to ask the speaker to repeat something as many times as the interlocutor might like. In many cases, listeners cannot predict what the speakers are going to say. For linguistic features, liaison and elision are considered as common phenomena that make it difficult for students to distinguish or recognize individual words in the stream of speech. They are used to seeing words written as discrete entities in their textbooks.

In addition, listening materials are made up of everyday conversation so speakers usually colloquial words or expressions as well as slang. Students who mainly study English through textbooks may not be familiar with these expressions. The listener is the next cause that students fail in understanding the content of the text. Foreign language students are not familiar enough with clichés and collocation in English to predict a missing word or phrase. In addition, lack of social cultural, factual, contextual knowledge of target language can become an obstacle to comprehend because language is a tool to express its culture. The next cause is the speaker. Most students tend to be familiar with their teachers' accent or to a standard variety of British or American English. So, it is hard for them to understand speakers with other accents. Physical setting such as noise including both background noises on the recording and environmental noises, the poor quality of the tapes or disks and the poor equipment's is the other cause hindering students in listening comprehension. However, Luchini and Arguello (2009) also said that L2 learners usually got certain difficulties and uncertainties in trying to understand the content in communication (p.322). With uncertainties, Hedge (2005) categorized into internal and external problems. Lacking motivation, high level of anxiety or knowledge of the topic under discussion and unknown vocabulary of what is heard can be considered as internal problems. With one of external problems is listeners' lack of understanding. As a result, the speakers fail to transmit successfully their message together with environmental noise. Besides these uncertainties, there are also other external factors such as the diversity of speakers' accent, the substitution, omission, and addition of certain sounds or differences in the use of intonation contours. A study of Yan (2006) has the same idea with Hedge (2005). His research expressed that subjects also got problems with speakers' accents. The length of listening taped-texts, the low quality of the recordings may be also significant external obstacles. The lack of knowledge of some 
listening strategies may contribute to prevent L2 learners' listening ability. For instance, the habit of listening word by word is believed to cause difficulty in listening process.

Different from Hedge, Underwood (1989) stated that there were seven causes affecting efficient listening comprehension. First, the listeners cannot catch or control the speed of speech. He said "the greatest difficulty with listening comprehension for many English language learners is they cannot control how quickly a speaker speaks". Second, it is difficult for students to have words repeated because in the classroom, teachers can not usually identify whether the students have understood any particular section of what they have heard or not (Underwood, 1989, p.17). Third, that is the limitation of vocabulary power of listeners. While speaking or communicating, speakers may choose words the listeners do not know. At that time, the listeners tend to find out the meaning of the words rather than concentrate on the context and thus cause missing the next part of the speech. It is examined in Chu's (2004) study and it is true. Fourth, it is hard for listeners to recognize the signals which indicate that the speaker is moving from one point to another. Fifth, listeners lack contextual knowledge such as mutual knowledge and common content. If they have enough amount of contextual knowledge, communicative process will happen more smoothly and more successfully. Sixth, it is difficult for listeners to concentrate in a foreign language. For example, if listeners have a short break in attention or neglect a moment in the listening process, it can seriously impair comprehension. Seventh, certain learning habits such as understanding every word is also one of factors make learners fail in listening comprehension.

In brief, there are many factors which influence the listening comprehension such as the speaker, the information, the listener and the environment. These factors limit the comprehension or the listening process. Therefore, it requires the strategies to enhance the learning process. The next part will present the learning strategies.

\subsection{The importance of learning strategies in language learning}

To be able to understand better about strategies in listening skill, this section shows the importance of strategies in learning a second language. This is one of useful factors that help to set up the theoretical background for the present thesis. It can be said that learning strategies are "the special thoughts or behavior" that learners apply to assist them to understand, learn and retain new information. Oxford (1990) describes language learning strategies as behaviors or action which language learners use to make learning successful, self-directed and enjoyable. O'Malley, Chamot and Kupper (1985) conducted a study on high school students who learned English as second language. They were assigned to receive learning strategy training on vocabulary, listening and speaking tasks. The results showed that this training can be effective for integrative language tasks. With benefits that learning strategies bring, Ellis (1985) concluded that "learning strategies are production sets that exist as declarative knowledge and are used to solve learning problem". In brief, learning strategies are very important to enhance students' proficiency and knowledge. 


\subsection{Strategies for listening comprehension}

Strategies can be seen as one of useful methods that help students become active in controlling their own learning. According to Vandergrift (1999), he said that "strategy development is important for listening training because strategies are conscious means by which learners can be guide and evaluate their own comprehension and response". In order to acquire success in the target language listening comprehension, learners need to use various strategies in their learning process. Therefore, it is necessary to classify listening strategies to help learners be easy to choose appropriate strategies in their listening process. Recently, some classifications of listening strategies have been proposed in order to make clear what kinds of listening strategies are. Firstly, according to Rubin's (1987) classification of language learning strategies, there are three types of strategies learners that contribute directly or indirectly to language learning. These are learning strategies, communication strategies and social strategies. Learning strategies consist of two main types contributing directly to development of learning. They are metacognitive strategies and cognitive strategies. Cognitive strategies are steps used to help learners solve some problems that require direct analysis, transformation or synthesis of learning material. Metacognitive strategies are used to oversee, regulate or self-direct language learning. They involve various processes such as planning, prioritizing, setting goals and selfmanagement. For communication strategies, they are less directly related to language learning since they focus on the process of participating in a conversation and getting meaning across or clarifying what speakers intended. These strategies are used when they get difficulties because their communication ends outrun their communication means. The final strategies are social strategies. They are activities which learners engage to afford them opportunities to be exposed to and practice their knowledge.

According to Oxford (1990), there are two general types of strategies. They are direct strategies which directly involve the subject matter and indirect strategies which do not directly involve the subject matter itself. Each of main types is further divided into 3 listening strategy groups. Direct strategies focus on three main types of strategies: memory, cognitive and compensation strategies. For instance, memory strategies support learners keep and recall the listening information. When listening to a message, they will use this strategy to store information and retrieve it when it is needed. Memory strategies include the following sub-strategies: creating mental linkage, applying images and sounds and using memory strategies for retrieval. About cognitive strategies, they are defined as actions or behaviors that learners involve during language learning, language use or language testing. They include practicing, receiving and sending messages; analyzing, reasoning, and creating structure for input and output. Compensation strategies are known as strategies which need to overcome any gaps in knowledge of language. Guessing intelligently and using other clues are potential compensation strategies. After referring to direct strategies, indirect strategies are also explained. Indirect strategies are also classified into three main kinds. The first one is meta-cognitive strategies which are considered self-management. These strategies help learners exercise 'executive control' through planning, arranging, focusing and evaluating their own 
language. The second one is affective strategies which learners use to control factors such as emotions, attitude, motivation and values. The last one is social strategies which facilitate interaction with others, often in a discourse situation. These sub-strategies are described in Appendix1. Different from classification for listening strategies of Oxford (1990), O' Malley and Chamot (1989) categorized listening strategies into three main types: meta-cognitive strategies, cognitive strategies and social-affective strategies and they are described in the following:

1) Meta-cognitive strategies are a kind of the self-regulated learning. It includes the attempt to plan, check, monitor, select, revise and evaluate. Generally, it can be discussed through pre-listening planning strategies, while-listening monitoring strategies and post-listening evaluation strategies. With pre-listening planning strategies, listeners will set a purpose to help them have better preparation before listening. While-listening monitoring strategies are strategies that listeners need to be 'self-conscious' while listening to be able to monitor their comprehension. For post-listening evaluation strategies, they are strategies that listening process is completed, listeners evaluate their overall comprehension progress and access how well they have done.

2) The cognitive strategies are related to comprehending and storing input in working memory or long-term memory for later retrieval. Cognitive strategies are the special actions that contribute directly to the learning processing. They are investigated from the aspects of bottom-up strategies and top-down strategies. For bottom-up processing, it refers to using the incoming input as the basic for understanding the message. Comprehension begins with the received data that are analyzed as successive levels of organization-sounds, words as a process of decoding. On the other hand, top-down processing strategies go from meaning to language (Richard, 2008). Learners can try to predict what will utter by signal. The listener employs prior knowledge of the context and situation within which the listening or message occurs to understand what the speaker speaks. "Context and situation involve such as knowledge of topic, the speakers and their correlation with the situation and previous events." (Gilakjani \& Ahmadi, 2011). The listening process can employ the top-down or bottom-up strategies. However, it depends on the levels of the learners or the purpose of listening such as listening to recognize sounds, words or understanding the meaning of the message that require bottom-up or top-down strategies or both. Chiu (2006) and Lu (2008) claimed that listening comprehension was neither top-down nor bottom-up processing. They should be combined to enhance listening comprehension.

3) Social-affective strategies are the strategies as the techniques listeners used to collaborate with others, to verify understanding or to lower anxiety. For social strategies, they are considered to be a 'social activity'. In learning situation there are always mixed ability groups within which learners can develop some appropriate strategies for sharing ideas or asking for help. Affective strategies are emotions, attitudes and values that learners need to help them control themselves. 
These strategies are considered as one of the biggest influences on language learning success or failure. Habte - Gabr (2006) also stated that social-affective strategies were those which were nonacademic in nature and involved stimulating learning through establishing a level of the empathy between the instructor and students. Therefore, it is essential for listeners to know how to reduce anxiety, feel confident in doing listening tasks and promote personal motivation in improving listening competence (Vandergrift, 1997). Among four strategies in listening comprehension including meta-cognitive, cognitive, social and affective strategies, both social and affective strategies influenced the learning situation immediately (O’Malley; Chamot, 1989).

The classification of listening comprehension strategy system proposed by O'Malley and Chamot (1989) is considered as a theoretical background of the investigation in the present study. Generally, applying strategies is very important for learners in listening competence. Little research has focused on which strategies employed when learners find that they cannot comprehend the information or message from contents of texts. This research specially intends to address the questions of what strategies the listeners employed to solve problems while listening.

\subsection{Previous studies on listening strategies and related studies on learning strategies}

There are many studies related to listening strategies that have been conducted by many scholars and researchers with many different aims. They would like to carry out these studies in order to identify what strategies that learners applied to enhance their comprehension, or how frequently these strategies are employed and the relationship between listening strategies. Some current studies related to this study are presented below

Jou's (2010) study concentrated to explore what strategies are frequently used by students at Technological University. She surveyed a sample of 239 students. A questionnaire and a test were used as tools to measure the degree of using strategies in listening process. The questionnaire consisted of 30 questions about strategies that participants applied in their listening comprehension tests and the test was adapted from the basic level of the GEPT (General English Proficiency Test). It was found that most students used strategies given in the questionnaire of learning listening. The results also showed that meta-cognitive strategies $\left(M_{\text {meta }}=3.52\right)$ were effective to improve their application of pre-listening planning, while-listening monitoring, and post-listening evaluation strategies. However, cognitive strategies $\left(M_{c o g}=3.61\right)$ were used the most effectively. In the terms of cognitive strategies, bottom-up strategies $(M=3.76)$ were applied more than top-down strategies $(M=3.58)$. For social and affective strategies, they were used positively with mean score $\left(M_{s o c}=3.5, M_{a f f} 3.26\right)$; however, strategies of be confident in understanding the whole contents was applied well especially for lowintermediate learners.

In Vandergrift's (2003) investigation, it aimed to examine the types and the differences of listening strategies used by more skilled and less skilled $7^{\text {th }}$ grade listeners 
when they listened to authentic texts in French. A think-aloud procedure was employed to gather the data and it was further analyzed quantitatively and qualitatively. The study lasted for 2 years as longitudinal investigation in which the progress of an experimental and control group of 36 learners was compared. The researcher used a taxonomy of listening comprehension strategies to code the think-aloud protocols. This taxonomy was divided into three major strategies (metacognitive, cognitive and social-affective) as well as the sub strategies within each category. The mean and percentage for the use of each strategy by the more skilled and less skilled listeners were calculated. Firstly, the quantitative analysis showed that all participants used metacognitive and cognitive strategies. The strategy that did not appear to be used was evaluation strategy. Next, the more skilled listeners gained more control of the listening process through the use of metacognitive strategies, primarily monitoring strategy and elaboration strategy. Finally, the less skilled listeners engaged in more direct translation. Their approach appeared to involve primarily bottom-up processing, which prevents the development of a conceptual framework and the efficient construction of the meaning. On the other hand, qualitative analysis also conducted to compare and capture the true phenomenon about how a given strategy was used or the particular combination of strategies used to build meaning. The results expressed that a less skilled listener engaged in translation and applied only a bottom-up approach. To sum up, the study shed light on listening strategies in several perspectives. First, more skilled listeners have tendency for applying metacognitive strategies to improve their listening skill. Next, less skilled listeners showed their frequent engagement in superficial translation strategies.

Lee (1997) explored the listening strategies used by 190 Taiwanese Junior College EFL students, including 150 females and 40 males. The participants completed the Chinese listening comprehension questionnaire, including 33 items. The finding identified that the most frequently used strategies involved asking speakers for repetition or paraphrasing to clarify comprehension (Mean $=3.80$ ), trying to understand each word $($ Mean $=3.79)$, self-questioning for comprehension (Mean $=3.54)$, and checking comprehension (Mean =3.45). On the other hand, the least frequently used strategies were thinking only in English (Mean =2.28), deciding in advance to listen for specific aspects of texts (Mean =2.23), listening for structures (Mean =1.95) and setting oneself up for tasks (Nil). Another study concerning learner's listening strategies was conducted by Goh (2002). The study was to identify the comprehension and learning listening strategies used by 118 Chinese ESL learners in a Singapore university. The results indicated that more proficient listeners used both cognitive and meta-cognitive strategies to achieve a meaningful interpretation of a text, and demonstrated the ability to use prior knowledge, linguistic cues and contextual information.

Chao's (1999) research investigated the strategies used by English majors while viewing an authentic English video text. Three hundred and sixteen students were randomly selected from six universities in Taiwan to participate in this study. The results showed that eight strategies with the highest mean reported by the subjects included grasping the overall meaning of the text (Mean=4.08), relate the text to what one already 
know the topic (Mean =3.96), focusing attention on the listening (Mean =3.95), clear one's mind (Mean $=3.78)$, relate to personal experience or knowledge (Mean $=3.76)$, guessing the meaning based on the context (Mean =3.75), set oneself up for the task (Mean = 3.69), and keeping up with the rate of speech (Mean =3.65). The subjects did not listen well for the grammatical structure (Mean $=2.35$ ). Briefly, the research findings showed that the learners tended to use top-down strategies more frequently than bottom-up strategies during listening. For example, "grasp the overall meaning of the text" and "relate the text to what I already know about the topic", got the highest and the second frequencies (4.08 and 3.96 respectively). Most of them tended to employ self-reliance strategies more frequently but tend to use social strategies least frequently. For instance, strategy for asking for help $(M=2.45)$ got the lowest average frequency of response

Peacock and Ho (2003) investigated the relationship between the use of LLSs and the proficiency level of 1006 English for Academic Purposes students in eight different majors in Hong Kong. The results of the study showed that there were significant correlations between strategy use and proficiency level. Cognitive and metacognitive strategies showed very high correlations with the proficiency level of the participants and were used by high-proficient learners. Compensation strategies, however, were shown to be favored by both high- and low-proficient students.

Zare-ee (2007) conducted a study reporting on an investigation into the relationship of test-takers' use of cognitive and metacognitive strategies to the EFL reading test performance. Data were collected from 30 randomly selected EFL learners studying English language and Literature at Kashan University, Iran. The participants included six male (20\%) and 24 female (80 \%) learners. SPSS version 13 was used to compute descriptive statistics, MANOVA and Pearson product moment correlations. Results obtained from conducting Pearson product moment correlations showed that the correlation between meta-cognitive strategies and cognitive strategies was .630 and it is significant at the 0.01 level. MANOVA also showed that students at higher levels of reading ability use meta-cognitive strategies more often that less successful readers. The findings of the study suggest that the use of meta-cognitive strategies can account for variation in EFL reading achievement and needs to be promoted by EFL teachers. Gender did not have a determining role in the use of either cognitive or meta-cognitive strategies in this study.

In brief, this chapter reviews this literature about definition of listening comprehension, significance of listening, factors affecting EFL learners' English listening comprehension, the importance of learning strategies, strategies for listening comprehension and previous studies on listening strategies. The next chapter will present the method of research.

\section{Research Method}

In the previous chapter, the literature on the major issues relating to the theoretical background of the study has been reviewed. In this chapter, the researcher will describe 
the research methods of the study including research questions and hypotheses the research design, participants, he researches instruments and the procedures of the study and data analysis.

\subsection{Research questions and hypothesis}

\subsubsection{Research questions}

In order to investigate the implementation of listening strategies in learning of English non-majored students, the researcher attempted to find out the answers to following questions:

1) Do English non-majored students use English listening strategies in their listening process?

2) To what extension do they apply these strategies?

3) Is there any relationship among these strategies?

\subsubsection{Hypotheses}

Through the literature review and the research questions, it was hypothesized that most of English non-majored students at Tay Do University would apply strategies in listening process. Moreover, these strategies would be useful tools in improving their listening comprehension in certain degree. Finally, there would be a significant relationship among these listening strategies.

\subsection{Research design}

The research was a qualitative and quantitative design. It was conducted on survey approach. According to Brown (1997), surveys are most often used in language education for research and for curriculum development. They can be used to answer the research questions that require description, explanation or explanation attitudes. In this descriptive study, students' listening strategies were examined. This study will be conducted to answer for the research questions and to test the hypothesis presented in the previous part. The main elements used to measure reliability and validity of the research are the target participants and research instruments. This chapter intends to show the readers the methodology of the study, including the profile of the participants, the instruments, and the procedures and data analysis.

\subsection{Participants}

The study was conducted from February to May of 2012. The participants in the research were 64 students studying Literature in class 6A and Banking Finance in class 6C at Tay Do University. All of them were English non-majored students; however, English was one of compulsory subjects in their credits. They were taught four skills of English language such as listening, speaking, reading and writing. Therefore, these freshmen were selected as the suitable subjects for the study. Their ages were ranged from 19 to 22 . Among 64 students, there were 13 male (20\%) and 51 female (80\%). Most of them have studied English at least 7 years. They study the same English textbook and the same 
studying environment. All of them speak Vietnamese as mother tongue and English was considered as their foreign language.

\subsection{Materials}

The participants in the present study are English non-majored students. They are firstyear students. The textbook used in their curriculum is General EL level 1. This textbook consists of four parts including conversation, grammar, reading and writing. There is no listening section. To help students increase their listening skill, teacher used Know-how textbook opener as extra source. This textbook has pictures or questions to guide students to the listening text. Besides, it has some exercises for students to check their comprehension.

\subsection{Research instruments}

\subsubsection{Designing questionnaire}

The questionnaire was adapted from the original version of Jou (2010) including 30 questions aiming at a study of English listening strategies applied by Technological University students. Besides that, there were some adjustments made according to the specific needs. The questionnaire (see Appendix 1) was designed to measure the use of English listening strategies in listening comprehensive process of students. The questionnaire consists of two parts. Part one is about participants' personal information. Part two consists of 31 items which were categorized into four clusters concerning metacognitive strategies, cognitive strategies, social strategies and affective strategies. Each item was presented as a statement to which students had to respond using a five-point Likert response scale label strongly agree, agree, no opinion, disagree and strongly disagree. To obtain a score the responses were allocated numerical values: strongly agree was score 5, agree 4, neutral 3, disagree 2, strongly disagree 1. The details are presented in Table 3.1.

For scale of this study, the questionnaire was designed in Vietnamese to avoid misunderstanding due to the participants' limited English proficiency

\subsubsection{Piloting questionnaire}

An initial draft of the questionnaire containing items to be included in the survey was reviewed by the researcher's supervisor and two former students of course 2 whose research was also on listening. Based on their specific comments and informed feedback regarding area that required further clarification, the survey format was restructured and several items in the survey were revised for improved clarity.

A pilot study was conducted using a sample of 40 English non-majored students. The results of the pilot showed a high reliability of the questionnaire with Cronbach's alpha value $(\propto)$ of 0.7993 (see Appendix 2). This showed that questionnaire was reliable to be used for collecting the quantitative data of the actual study. 


\subsubsection{Conducting questionnaire}

In the first part of personal information, subjects were supposed to fill out the gender, age and major. The second part of the questionnaire consists of 31 items about listening strategies measured on a five point scale. The participants could only choose one in five points (strongly agree, agree no opinion, disagree, strongly disagree). The time allocated for conducting 31 items in the questionnaire is 30 minutes. The data from the questionnaire were collected and analyzed.

\subsection{Procedure}

The study was conducted during 16 weeks from February to May of 2012. It consists of four stages. In the first stage, the information was collected from newspapers, articles, and internet. After consulting and collecting enough information for the study, the questionnaire was designed in the second stage. The third stage was undertaken three weeks later. In the third stage, there were 64 students in total selected to complete the questionnaire. After that, the data collected would be analyzed at the fourth stage. Then, the paper was completed.

\subsection{Data analysis}

The data gathered through questionnaire were analyzed. First, they were coded for statistical analysis. Then they were divided into clusters of strategies to answer research questions indicated above. The data were coded and prepared for analysis using the Statistics Package for the Social Sciences (SPSS) version 11.5. In order to answer the research questions (see part 3.1.1 of this chapter), the researcher utilized two analytical tests. First, the scale test (see Appendix 2) was conducted to check the reliability of the questionnaire. Then, the descriptive statistics test was computed to determine the minimum, the maximum, the mean score and the standard deviation.

In summary, this chapter has presented the research method of the study in detail. The research findings obtained in the survey questionnaire are described in the next chapter.

\section{Research Results}

This chapter aims to report the results of the data collection based on the questionnaire. The results showed the statistical evidence on the general result, meta-cognitive strategies, cognitive strategies, social strategies, affective strategies.

\subsection{The general result}

In chapter 3, a piloting questionnaire was conducted to examine the reliability of questionnaire and the result was very satisfactory with high reliability coefficient alpha $(\alpha)=.7993)$. Similarly, questionnaire used for this study also has high reliability coefficient with alpha $(\alpha)=.7985$ (see Appendix 3). 
To find out which strategy used most in listening process, the data collected from the questionnaire were calculated on SPSS including Descriptive Statistics Test and OneSample T-Test to analyze mean and standard deviation on participants' listening strategies. The results of the questionnaire were shown in the following Table 4.1.

Table 4.1: The mean score of English listening strategies

\begin{tabular}{|l|c|c|c|c|c|c|}
\hline Clusters & $\mathbf{N}$ & Min & Max & Mean & SD & Percentage (\%) \\
\hline Meta-cognitive strategies & 64 & 2.90 & 4.50 & 3.64 & .35087 & 84.69 \\
\hline Cognitive strategies & 64 & 2.58 & 4.75 & 3.61 & .45130 & 85.19 \\
\hline Social strategies & 64 & 2.20 & 5.00 & 4.03 & .53637 & 93.78 \\
\hline Affective strategies & 64 & 2.25 & 5.00 & 3.46 & .52242 & 81.28 \\
\hline
\end{tabular}

As can be seen in Table 4.1, most of strategies from meta-cognitive to affective strategies were applied much and the mean scores are higher than the excepted scale (scale 3 ). Among them, social strategies gain the highest with the mean score $4.03\left(M_{s o c}=4.03\right)$ accounting for $93.78 \%$. Besides, the second strategies which are used more include metacognitive strategies and cognitive strategies. The mean score for meta-cognitive strategies is $3.64\left(M_{\text {meta }}=3.64\right)$ accounting for $84.69 \%$ and cognitive strategies is 3.61 ( $\left.M_{c o g}=3.61\right)$ accounting for $85.19 \%$. Although affective strategies are not used as much as these above strategies, the mean score is still high (Maff $=3.46)$ accounting for $81.28 \%$. Figure 4.1 and Figure 4.2 illustrate more clearly about the mean score and percentage of English listening strategies used by students.

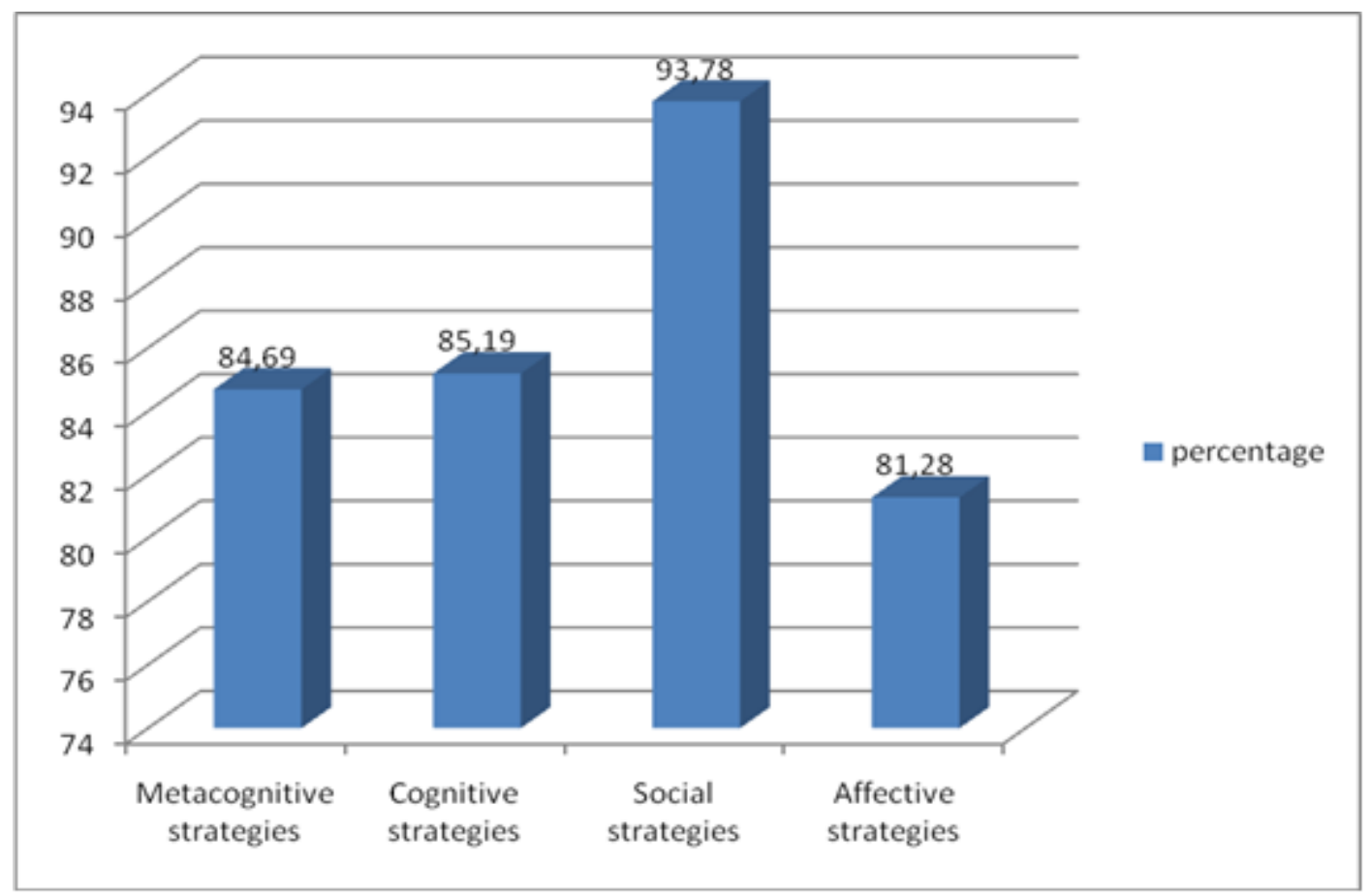

Figure 4.1: The percentage of English listening strategies use 
Table 4.2: One-Sample T-Test of listening strategies

\begin{tabular}{|c|c|c|c|c|c|c|}
\hline & \multicolumn{6}{|c|}{ Test Value $=3$} \\
\hline & \multirow[t]{2}{*}{$\mathbf{t}$} & \multirow[t]{2}{*}{ Df } & \multirow{2}{*}{$\begin{array}{l}\text { Sig. (2- } \\
\text { tailed) }\end{array}$} & \multirow{2}{*}{$\begin{array}{c}\text { Mean } \\
\text { Difference }\end{array}$} & \multicolumn{2}{|c|}{$\begin{array}{l}\text { 95\% Confidence Interval of the } \\
\text { Difference }\end{array}$} \\
\hline & & & & & Lower & Upper \\
\hline MEANMETA & 14,642 & 63 &, 000 & ,6422 & ,5545 & ,7298 \\
\hline MEANCOG & 10,802 & 63 & , 000 & 6094 & ,4966 & ,7221 \\
\hline MEANSOCI & 15,428 & 63 & , 000 & 1,0344 & ,9004 & 1,1684 \\
\hline MEANAFF & 6,999 & 63 & ,000 & 4570 & ,3265 &, 5875 \\
\hline
\end{tabular}

Continuously, Table 4.2 will analyze the participants' use of four main kinds of listening strategies on their listening process.

Table 4.2: One-Sample T-Test of listening strategies

\begin{tabular}{|c|c|c|c|c|c|c|}
\hline & \multicolumn{6}{|c|}{ Test Value $=3$} \\
\hline & \multirow[t]{2}{*}{$\mathbf{t}$} & \multirow[t]{2}{*}{ Df } & \multirow[t]{2}{*}{ Sig. (2-tailed) } & \multirow{2}{*}{$\begin{array}{c}\text { Mean } \\
\text { Difference }\end{array}$} & \multicolumn{2}{|c|}{$\begin{array}{c}95 \% \text { Confidence Interval } \\
\text { of the Difference }\end{array}$} \\
\hline & & & & & Lower & Upper \\
\hline MEANMETA & 14,642 & 63 & 000 & 6422 & 5545 & ,7298 \\
\hline MEANCOG & 10,802 & 63 & ,000 & 6094 & ,4966 & ,7221 \\
\hline MEANSOCI & 15,428 & 63 & ,000 & 1,0344 & 9004 & 1,1684 \\
\hline MEANAFF & 6,999 & 63 & 000 & 4570 & 3265 & 5875 \\
\hline
\end{tabular}

The results from the Table 4.2 show that the mean scores of the listening strategies are statistically significant with $p=<.005$ (meta-cognitive strategies $(t=14.642, d f=63)$, cognitive strategies $(t=10.802, d f=63)$, social strategies $(t=15.428, d f=63)$, affective strategies $(t=6.999$, $d f=63)$. The results support the conclusion that participants employed all of these strategies in their listening comprehension.

\subsection{The results of each kind of strategies}

\subsubsection{Meta-cognitive strategies}

The data were calculated in SPSS and classified into different strategies. First of all, the metacognitive strategies were analyzed in three categories including pre-listening strategies, while-listening strategies and post-listening strategies.

\subsubsection{Pre-listening planning strategies}

The results of pre-listening strategies are shown in Table 4.3.

Table 4.3: Pre-listening planning strategies

\begin{tabular}{|l|c|c|c|c|c|}
\hline Items & Min & Max & Mean & Std. Deviation & \% \\
\hline Q1 & 3 & 5 & 4.31 & .588 & 100 \\
\hline Q2 & 1 & 5 & 2.84 & .979 & 59.4 \\
\hline Q3 & 2 & 5 & 4.09 & .660 & 98.4 \\
\hline
\end{tabular}


As can be seen in Table 4.3, most of all students prepare their mind to concentrate before listening $\left(M_{\mathrm{Q} 1}=4.31\right)$ accounting for $100 \%$. Besides, to understand the content of the text, students usually identify the purposes of language activities before listening $\left(M_{Q 3}=4.09\right)$. It accounts for $98.4 \%$. Unlike these two items above, students do not like much about their progress in learning English $\left(M_{Q_{2}}=2.84\right)$ accounting for $59.4 \%$. Gareth Rees (2003) shows that when pre-listening strategies are well prepared, they can help to create confidence and facilitate listening comprehension. Chang (2008) also stated that before listening to the text, previewing questions was helpful to the learner's comprehension. From the result, it can be seen that not all strategies are applied well by students. Before listening, maybe they only think about some elements that help them to understand the contents of the texts such as keeping their mind to concentrate or identifying the purposes of the language activities. Thinking about their progressing in learning English is not important to them.

\subsubsection{While-listening monitoring strategies}

The results of while-listening strategies are shown in Table 4.4.

Table 4.4: While-listening monitoring strategies

\begin{tabular}{|l|c|c|c|c|c|}
\hline Items & Min & Max & Mean & SD & \% \\
\hline Q6 & 1 & 5 & 2.73 & 1.102 & 54.8 \\
\hline Q7 & 1 & 5 & 3.56 & .990 & 82.8 \\
\hline Q8 & 2 & 5 & 3.83 & .827 & 90.6 \\
\hline Q9 & 1 & 5 & 3.39 & 1.048 & 81.3 \\
\hline
\end{tabular}

The Table 4.4 shows that in while listening stage, most of students showed significant attention about being willing to check what part of content they did not know $\left(M_{Q 7}=3\right.$, $56)$ accounts for $82.8 \%$ and double checking again for their answers ( $\left.M_{Q 8}=3.83\right)$ accounts for $90,6 \%$.Continuously, the results also showed that many students agreed they usually lose concentration while listening, but it is corrected when doing listening test $\left(M_{Q 9}=3.39\right)$ accounts for $81.3 \%$. However, strategy six $\left(M_{\mathrm{Q} 6}=2.73\right)$ accounts for $54.8 \%$ was not used effectively by students. In fact, most of students thought that speakers' accent was a source that caused difficulty for them in listening process. Yan's (2006) study showed that there were about $66.25 \%$ of learners getting problems with speakers' accents and he believed that unfamiliar accents might hinder listeners from understanding the contents. It is similar with Yan's study.

\subsubsection{Post-listening evaluation strategies}

Q26, 27, 28 addressed the cluster of participants' using of post-listening evaluation strategies. The results concerning this cluster are shown in Table 4.5. 
Table 4.5: Post-listening evaluation strategies

\begin{tabular}{|l|c|c|c|c|c|}
\hline Items & Min & Max & Mean & SD & \% \\
\hline Q26 & 1 & 5 & 3.81 & .941 & 90.6 \\
\hline Q27 & 2 & 5 & 4.08 & .650 & 98.4 \\
\hline Q28 & 2 & 5 & 3.77 & .921 & 90.6 \\
\hline
\end{tabular}

As can be seen in Table 4.5, it is clear that all strategies are employed regularly and effectively by students. In fact, item 27 is strategy used the most with mean score $\left(M_{Q_{2} 7}=4.08\right)$ accounting for $98.4 \%$. After listening, students evaluate the degree that they can understand. That is a good way for them to improving listening next time. Similarly, items 26 and 28 were strategies accepted actively by students although their mean score is not as high as item 27. Most students find out the problems that they have to face such as the key words that they do not $\left(M_{026}=3.81\right)$ accounting for $90.6 \%$. According to Chu (2004), most of listeners have a limited vocabulary so they will feel confused when they hear some words they cannot figure out. And in this study, there are more than a half of participants agreeing with looking up the new vocabulary in the dictionary with mean score $\left(M_{Q 28}=3,77\right)$. It accounts for $90.6 \%$.

\subsubsection{The results of using 3 kinds of meta-cognitive strategies}

The comparison of the three strategies of metacognitive use is shown in the Table 4.6 below.

Table 4.6: The mean score of using 3 kinds of meta-cognitive strategies

\begin{tabular}{|l|c|c|c|c|c|c|}
\hline & N & Min & Max & Mean & SD & \% \\
\hline Pre-listening & 64 & 2.67 & 4.67 & 3.75 & .48250 & 85.9 \\
\hline While-listening & 64 & 2.25 & 4.50 & 3.38 & .52325 & 77.4 \\
\hline Post-listening & 64 & 2.67 & 5.00 & 3.89 & .57954 & 93.2 \\
\hline
\end{tabular}

The Table 4.6 shows that three kinds of above strategies are used highly in listening practice. Especially, the mean score of post-listening evaluation strategies is the highest among three with mean score is 3.89 which accounts for $93.2 \%$. Next, the mean score of pre-listening planning strategies is 3.75 accounting for $85.9 \%$ and the last is 3.38 accounting for $77.4 \%$. Figure 4.3 and Figure 4.4 illustrate Table 4.6 clearly. 


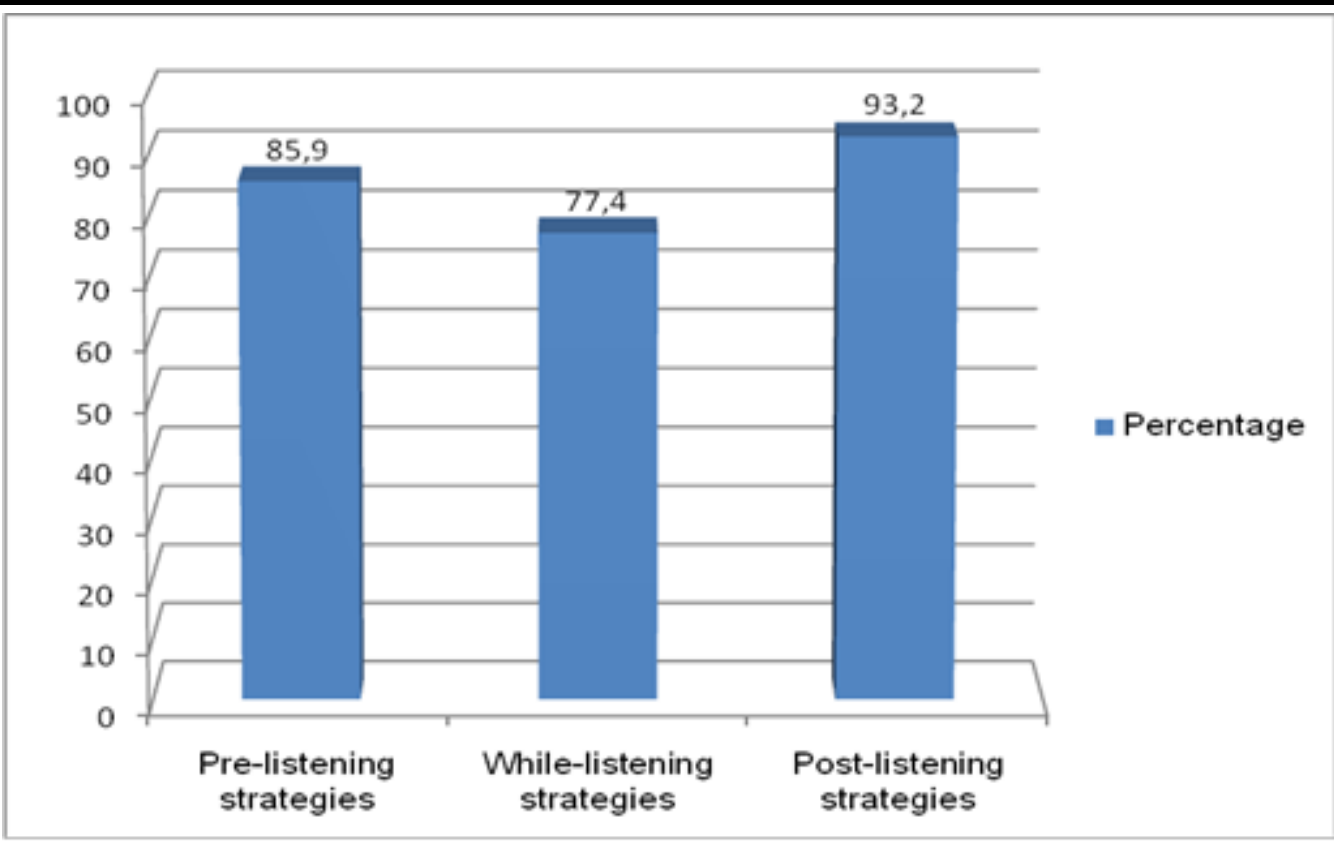

Figure 4.3: The percentage of 3 kinds of meta-cognitive strategies

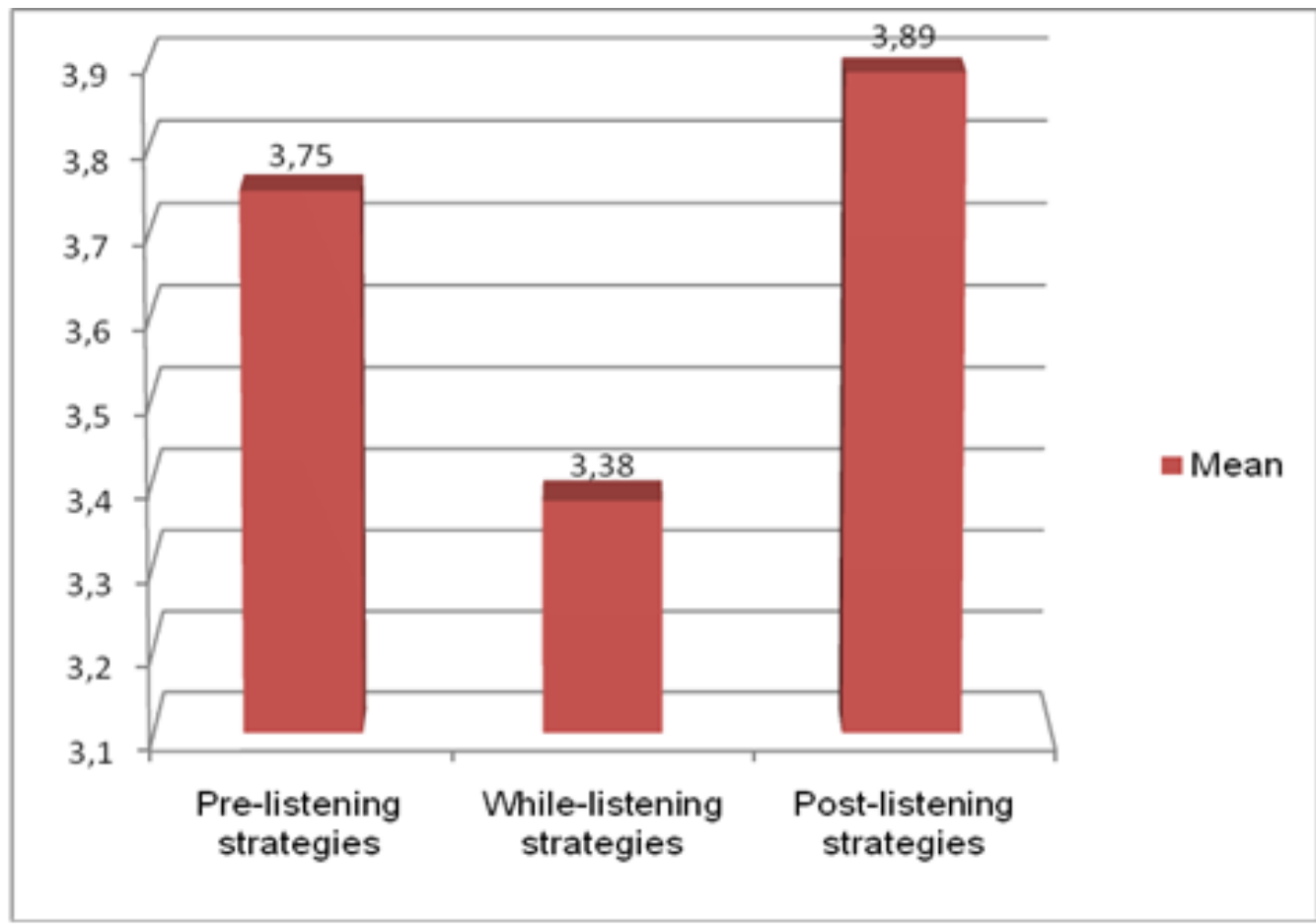

Figure 4.4: The mean score of 3 kinds of meta-cognitive strategies

\subsubsection{Cognitive strategies}

The data collected from the questionnaire were analyzed in term of cognitive strategies.

\subsubsection{Cognitive formal practicing strategies}

The results of cognitive formal practicing strategies are presented in Table 4.7 below. 
Table 4.7: Cognitive formal practicing strategies

\begin{tabular}{|l|c|c|c|c|c|}
\hline Items & Min & Max & Mean & Std. Deviation & \% \\
\hline Q10 & 1 & 5 & 3.84 & .996 & 84.4 \\
\hline Q13 & 1 & 5 & 3.78 & .983 & 87.5 \\
\hline Q31 & 1 & 5 & 4.00 & .909 & 95.3 \\
\hline
\end{tabular}

The mean score for each question in Table 4.7 is higher than the average scale $(M=3.0)$. This also means that the participants admitted the benefits that these strategies bring to them. Actually, most of students think that practicing listening to EL actively in daily life, such as listening to English news, English songs on TV or radio, talking to foreigners will increase interest in learning English $\left(M_{031}=4.0\right)$. It accounts for $95.3 \%$. Another strategy accepted much by students while listening is that they like to translate words or sentences into Vietnamese $\left(M_{\mathrm{Q} 10}=3.84\right)$ accounting for $84.4 \%$. The results from this table also indicate that students like applying the new vocabulary, phrases or grammar they have learned to understand the contents $\left(M_{\mathrm{Q} 13}=3.78\right)$. It accounts for $87.5 \%$.

\subsubsection{Bottom-up Strategies}

The results of bottom-up strategies are presented in Table 4.8 below.

Table 4.8: Bottom-up strategies

\begin{tabular}{|l|c|c|c|c|c|}
\hline Items & Min & Max & Mean & Std. Deviation & \% \\
\hline Q11 & 2 & 5 & 3.33 & .818 & 86 \\
\hline Q12 & 1 & 5 & 3.53 & 1.083 & 78.2 \\
\hline Q14 & 2 & 5 & 3.61 & .902 & 86 \\
\hline Q17 & 2 & 5 & 3.92 & .741 & 95.4 \\
\hline
\end{tabular}

The bottom-up strategies tend to understand the details such as words or phrases of content. The Table 4.8 shows that most students usually pay attention to words or sentence stresses to enhance their understanding $\left(M_{017}=3.92\right)$ accounting for $95.4 \%$ and often repeat words or phrases softly and mentally $\left(M_{\mathrm{Q} 14}=3.61\right)$ accounting for $86 \%$. Besides, to grasp the content of the text, students also try to understand each word $\left(M_{\mathrm{Q} 12}=3.53\right)$ account for $78.2 \%$. Like items 14, items 11 implies that students may like to put details together to understand what the sentences meant, especially noticing the information questions with who, whom, which, how, where ....(M011=3.33). This study is the same with Jou's study (2010). Participants tend to take notes the information questions to enhance the content. Actually, to be able to apply bottom-up strategies effectively, learner should widen vocabulary largely enough and have good knowledge of sentence structure. Traditionally, exercises of cloze listening or the use of multiple-choice questions are applied to process the bottom-up strategies. Richard (2008, cited by Jou's study, p110) stated that "the recognition of key words, transition in a discourse, grammatical relationships between elements in sentences and use stress, intonation to identify word and sentence functions where the essential elements in processing bottom-up strategy". Bottom-up strategies helps students enhance knowledge of vocabulary and grammar. 


\subsubsection{Top-down strategies}

Q15, 16, 18, 19, 29 addressed the cluster of participants' using of top-down strategies. The results of bottom-up strategies are presented in Table 4.9 below.

Table 4.9: Top-down strategies

\begin{tabular}{|l|c|c|c|c|c|}
\hline Items & Min & Max & Mean & Std. Deviation & \% \\
\hline Q15 & 2 & 5 & 3.80 & .929 & 90.7 \\
\hline Q16 & 1 & 5 & 3.77 & .811 & 93.8 \\
\hline Q18 & 1 & 5 & 3.39 & .953 & 82.8 \\
\hline Q19 & 1 & 5 & 2.95 & 1.015 & 64 \\
\hline Q20 & 2 & 5 & 3.39 & .936 & 78.2 \\
\hline
\end{tabular}

Top-down skills are also important strategies in listening comprehension. The results from Table 4.9 show that most of strategies were employed effectively by most of students in improving listening comprehension. For example, students agreed that they listened for main ideas first and then details $\left(M_{Q 15}=3.80\right)$ accounting for $90.7 \%$ and predicting or making hypotheses on texts by titles with mean score ( $M_{016}=3.77$ ) accounting for $93.8 \%$. In addition, they also guessed the meaning of words based on the content and while listening, they formed pictures mentally to help learners comprehend texts are equal $\left(M_{18}=M_{20}=3.39\right)$. In contract, most of students were not familiar with trying to think in English instead of Vietnamese and the mean score is below the average scale $\left(M_{Q 19}=2.95\right)$ accounting for $64 \%$. To sum up, students used successfully top-down strategies, but they still think in Vietnamese while listening. As a result, it slows down listening processing. Therefore, they needed more guidance from teacher to develop topdown skills.

\subsubsection{The results of using 3 kinds of cognitive strategies}

The comparison of the three kinds of cognitive strategies is shown in the Table 4.10.

Table 4.10: The mean score of using 3 kinds of cognitive strategies

\begin{tabular}{|l|c|c|c|c|c|c|}
\hline & N & Min & Max & Mean & SD & \% \\
\hline Formal practicing & 64 & 2.00 & 5.00 & 3.88 & .66534 & 89 \\
\hline Bottom-up & 64 & 2.50 & 4.75 & 3.60 & .53008 & 86.4 \\
\hline Top-down & 64 & 2.20 & 4.60 & 3.46 & .53414 & 81.9 \\
\hline
\end{tabular}

As seen from Table 4.10, most of mean scores of 3 kinds of cognitive strategies are higher than scale 3. This indicates that all of these strategies are very useful for students such cognitive formal practicing strategies $(M=3.88)$ accounts for $89 \%$ were applied more than bottom-up strategies $(M=3.60)$ accounts for $86.4 \%$ and top-down strategies $(M=3.46)$ accounts for $81.9 \%$. Figure 4.5 and 4.6 illustrate the results of using 3 kinds of cognitive strategies. 


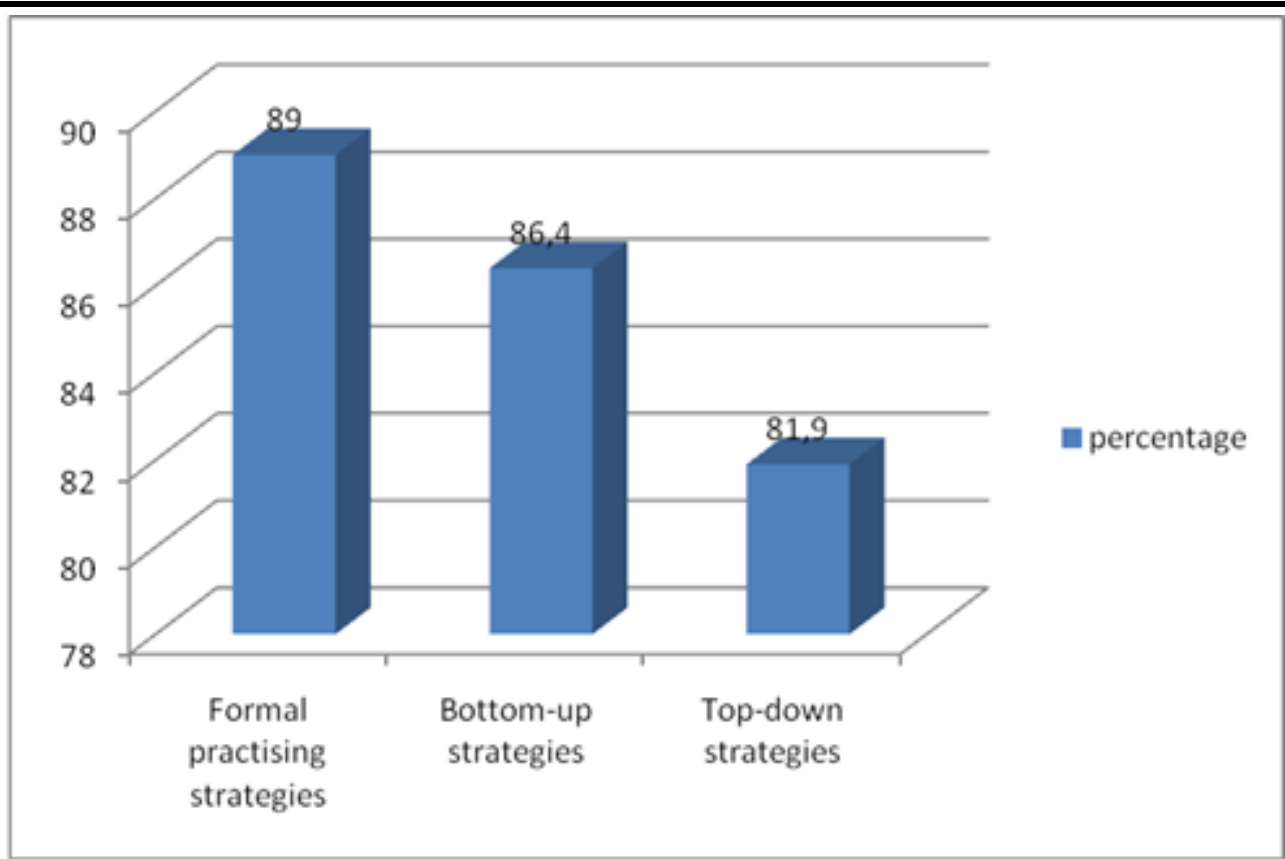

Figure 4.5: The percentage of 3 kinds of cognitive strategies

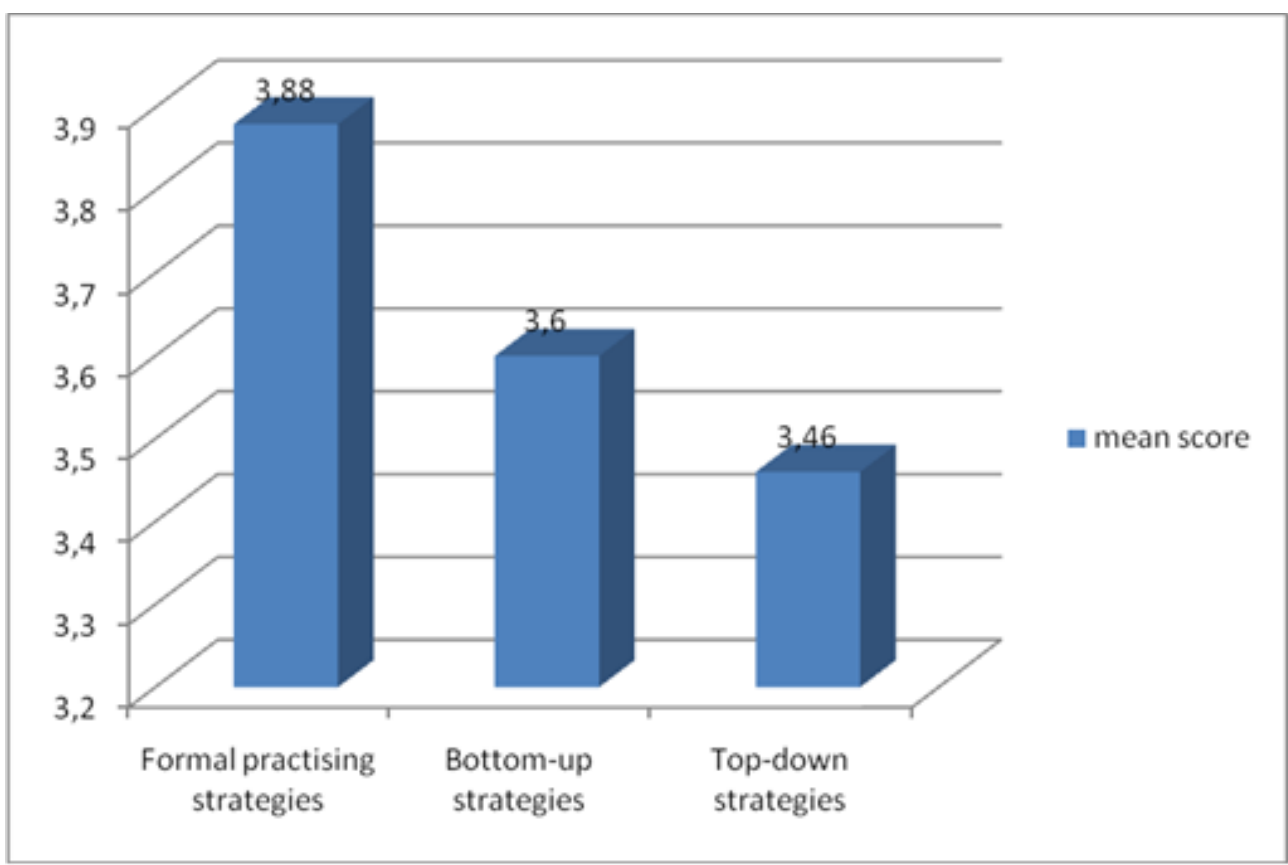

Figure 4.6: The mean score of 3 kinds of cognitive strategies

\subsubsection{Social strategies}

The data collected from the questionnaire were analyzed in term of social strategies. 
Table 4.11: Social strategies

\begin{tabular}{|l|c|c|c|c|c|}
\hline Items & Min & Max & Mean & SD & \% \\
\hline Q22 & 1 & 5 & 4.14 & .924 & 92.2 \\
\hline Q23 & 1 & 5 & 3.47 & 1.083 & 84.4 \\
\hline Q24 & 2 & 5 & 4.17 & .747 & 95.4 \\
\hline Q29 & 2 & 5 & 4.09 & .684 & 98.4 \\
\hline Q30 & 2 & 5 & 4.30 & .683 & 98.4 \\
\hline
\end{tabular}

The results of Table 4.11 indicate that most students think teachers play an important role in improving listening comprehension such as teaching them more skills $\left(M_{\mathrm{Q} 30}=4.30\right)$ which accounts for $98.4 \%$. In item 22 and 24, students show their positive attitude in asking English speaking people to repeat what they do not understand $\left(M_{\mathrm{Q} 22}=4.14\right)$ which accounts for $92.2 \%$ and to slow down when they speak fast high $\left(M_{\mathrm{Q} 24}=4.17\right)$ accounting for $95.4 \%$. In addition, most students usually asked their classmates or teachers questions they did not understand after listening with mean score $\left(M_{Q_{2} 2}=4.09\right)$ accounting for $98.4 \%$. Strategy in item 23 about asking English speakers to correct them when they talk is applied much $\left(M_{23}=3.47\right)$. The degree for applying this strategy is less high than degree for applying other ones. It accounts for $84.4 \%$. It can be concluded that all of social strategies were employed effectively by students.

\subsubsection{Affective strategies}

The data collected from the questionnaire were analyzed in term of affective strategies.

Table 4.12: Affective strategies

\begin{tabular}{|l|c|c|c|c|c|}
\hline Items & Min & Max & Mean & SD & Percentage (\%) \\
\hline Q4 & 2 & 5 & 3.66 & .801 & 93.8 \\
\hline Q5 & 1 & 5 & 2.44 & .871 & 42.3 \\
\hline Q21 & 1 & 5 & 3.86 & .852 & 93.7 \\
\hline Q25 & 2 & 5 & 3.88 & .807 & 95.3 \\
\hline
\end{tabular}

In affective strategies, the results show that most of students relax whenever they feel afraid of using English $\left(M_{\mathrm{Q} 25}=3.88\right)$. It accounts for $95.3 \%$. They try to keep calm and are not nervous $\left(M_{\mathrm{Q} 21}=3.86\right)$ accounting for $93.7 \%$. Besides, students also find out some methods to reduce their anxiety while listening such as encourage themselves through positive self-talk $\left(M_{Q 4}=3.66\right)$ accounting for $93.8 \%$. However, item 5 implies that most students are not confident enough in understanding the whole contents $\left(M_{\mathrm{Q} 5}=2.44\right)$ accounting for $42.3 \%$.

\subsection{The relationship between kinds of listening strategies}

In this chapter, besides comparing degrees of using listening strategies in listening comprehension, it also shows whether strategies have their correlation together. Pearson Correlation was applied to measure of these strategies. Table 4.13 will provide the actual value of correlation coefficient between metacognitive and cognitive strategies. 
Table 4.13: The correlation between metacognitive and cognitive strategies

\begin{tabular}{|l|l|c|c|}
\hline \multirow{4}{*}{ MEANMETA } & & MEANMETA & MEANCOG \\
\cline { 2 - 4 } & Pearson Correlation & 1 &, $447\left({ }^{* *}\right)$ \\
\cline { 2 - 4 } & Sig. (2-tailed) &. &, 000 \\
\cline { 2 - 4 } & $\mathrm{N}$ & 64 & 64 \\
\hline \multirow{3}{*}{ MEANCOG } & Pearson Correlation &, $447\left({ }^{* *}\right)$ & 1 \\
\cline { 2 - 4 } & Sig. (2-tailed) & 600 & 64 \\
\cline { 2 - 4 } & $\mathrm{N}$ & 64 & 64 \\
\hline
\end{tabular}

** Correlation is significant at the 0.01 level (2-tailed).

Table 4.13 shows the correlation of these two strategies is ' .447 ' and p-value is '.000' $(p=.000)$. The result indicates that the correlation between metacognitive and cognitive strategies is statistically significant. Table 4.14 presents the correlation coefficient between cognitive and social strategies.

Table 4.14: The correlation between cognitive and social strategies

\begin{tabular}{|l|l|c|c|}
\hline \multirow{3}{*}{ MEANCOG } & & MEANCOG & MEANSOCI \\
\hline \multirow{3}{*}{ MEANSOCI } & Pearson Correlation & 1 &, $\left.5366^{(* *}\right)$ \\
\cline { 2 - 4 } & Sig. (2-tailed) &. &, 000 \\
\cline { 2 - 4 } & $\mathrm{N}$ & 64 & 64 \\
\cline { 2 - 4 } & Pearson Correlation &, $536\left(^{* *}\right)$ & 1 \\
\cline { 2 - 4 } & Sig. (2-tailed) &, 000 &. \\
\cline { 2 - 4 } & $\mathrm{N}$ & 64 & 64 \\
\hline
\end{tabular}

** Correlation is significant at the 0.01 level (2-tailed).

Table 4.14 implies the correlation of these two strategies is '.536' and p-value is '.000' ( $p=.000$ ). And like Table 13, the result shows that the correlation is statistically significant. It means that there is a correlation between cognitive and social strategies. Similarly, between cognitive and affective strategies exist a relationship with their correlation coefficient is '.536' and p-value is '.000'. So, it can be said that the correlation is statistically significant. The following table demonstrates how the relationship between variables of cognitive and affective strategies is manifested.

Table 4.15: Correlation between cognitive and affective strategies

\begin{tabular}{|l|l|c|c|}
\hline \multirow{4}{*}{ MEANCOG } & & MEANCOG & MEANAFF \\
\cline { 2 - 4 } & Pearson Correlation & 1 &, $496\left(^{* *}\right)$ \\
\cline { 2 - 4 } & Sig. (2-tailed) &. &, 000 \\
\cline { 2 - 4 } & $\mathrm{N}$ & 64 & 64 \\
\hline \multirow{3}{*}{ MEANAFF } & Pearson Correlation &, $496\left(^{* *}\right)$ & 1 \\
\cline { 2 - 4 } & Sig. (2-tailed) &, 000 & 64 \\
\cline { 2 - 4 } & $\mathrm{N}$ & 64 &. \\
\hline
\end{tabular}

\footnotetext{
** Correlation is significant at the 0.01 level (2-tailed).
} 
Continuously, metacognitive and affective strategies have relationship with correlation '.218' and p-value '.025'. The results showed the correlation is not significant. However, they are related. Table 4.16 presents correlation between metacognitive and affective strategies.

Table 4.16: Correlation between metacognitive and affective strategies

\begin{tabular}{|l|l|c|c|}
\hline \multirow{4}{*}{ MEANMETA } & & MEANMETA & MEANAFF \\
\cline { 2 - 4 } & Pearson Correlation & 1 &, $281\left(^{*}\right)$ \\
\cline { 2 - 4 } & Sig. (2-tailed) &. &, 025 \\
\cline { 2 - 4 } & $\mathrm{N}$ & 64 & 64 \\
\hline \multirow{3}{*}{ MEANAFF } & Pearson Correlation &, $281\left(^{*}\right)$ & 1 \\
\cline { 2 - 4 } & Sig. (2-tailed) &, 025 & 64 \\
\cline { 2 - 4 } & $\mathrm{N}$ & 64 & 6 \\
\hline
\end{tabular}

* Correlation is significant at the 0.05 level (2-tailed).

The result between metacognitive and social strategies is summarized in the Table 4.17.

Table 4.17: The correlation between metacognitive and social strategies

\begin{tabular}{|l|l|c|c|}
\hline \multirow{4}{*}{ MEANMETA } & & MEANMETA & MEANSOCI \\
\cline { 2 - 4 } & Pearson Correlation & 1 & .227 \\
\cline { 2 - 4 } & Sig. (2-tailed) &. & .072 \\
\cline { 2 - 4 } & $\mathrm{N}$ & 64 & 64 \\
\hline \multirow{3}{*}{ MEANSOCI } & Pearson Correlation & .227 & 1 \\
\cline { 2 - 4 } & Sig. (2-tailed) & .072 &. \\
\cline { 2 - 4 } & $\mathrm{N}$ & 64 & 64 \\
\hline
\end{tabular}

From this table, it indicates that there is a correlation between these two kinds of strategies (.227). However, this relationship is not statistically with $p>.005$. Likewise, the relationship between social and affective strategies is also not statistically significant. The results are presented in the following table.

Table 4.18: Correlation between social and affective strategies

\begin{tabular}{|l|l|c|c|}
\hline \multirow{4}{*}{ MEANAFF } & & MEANAFF & MEANSOCI \\
\cline { 2 - 4 } & Pearson Correlation & 1 & .218 \\
\cline { 2 - 4 } & Sig. (2-tailed) &. & .084 \\
\cline { 2 - 4 } & $\mathrm{N}$ & 64 & 64 \\
\hline \multirow{3}{*}{ MEANSOCI } & Pearson Correlation & .218 & 1 \\
\cline { 2 - 4 } & Sig. (2-tailed) & .084 &. \\
\cline { 2 - 4 } & $\mathrm{N}$ & 64 & 64 \\
\hline
\end{tabular}

To sum up, there is a significant relationship between metacognitive and cognitive strategies, between cognitive and social strategies, between cognitive and affective strategies. However, the relationships between metacognitive and social strategies, between metacognitive and affective strategies, between social and affective strategies are not significant. 


\subsection{Conclusion}

After collecting and analyzing data, the results from this chapter showed that most of strategies were used by English non-major students at Tay Do University. However, the degree of using is different. Social strategies were employed most with mean score ( $M_{s o c}=$ 4.03). Metacognitive strategies were the ensuing ones used much $\left(M_{m e t a}=3.64\right)$. The next ones were cognitive strategies $\left(M_{c o g}=3.61\right)$ and the last ones were affective strategies $\left(M_{a f f}=3.46\right)$. When examining the relationship between strategies, it could be found that they had correlation together with existing significant value ' $\mathrm{p}<.005$ ' such as between metacognitive and cognitive strategies, between cognitive and social strategies and between cognitive and affective strategies. However, pairs of strategies such as metacognitive and social strategies, metacognitive and affective strategies, social and affective strategies were not statistically significant ' $\mathrm{p}>.005$ '. In general speaking, English non-majored students at Tay Do University applied listening strategies in listening comprehension.

\section{Discussions and Conclusions}

This chapter presents Discussions about the results, Limitations of this study, suggestions for further research, Implication for teaching and learning listening strategies and Conclusion of the thesis.

\subsection{Discussions about the results}

\subsubsection{Listening strategies applied by English non-majored students}

From the results of chapter 4, question one and two of research questions in chapter 3 "do English non-majored students use English listening strategies in their listening process?" and " to what extension do they apply these strategies?" were answered. The results revealed that most participants in this thesis used listening strategies in English language learning. The social strategies $\left(M_{s o c}=4.03\right)$ were employed at the highest end of the frequency scale followed by metacognitive strategies $\left(M_{\text {meta }}=3.64\right)$ and cognitive strategies $\left(M_{c o g}=3.61\right)$. Finally, that is affective strategies $\left(M_{a f f}=3.46\right)$. The results of this study are partly consistent with Jou's (2010) study. Like his findings, it can be said that most of strategies were applied. However, the degrees of using these strategies in listening process are different. In his study, the highest used strategies are cognitive strategies $\left(M_{c o g}=3.61\right)$ as in this study, that is social strategies $\left(M_{s o c}=4.03\right)$. The least used strategies are affective strategies $\left(M_{a f f}=3.46\right)$ and this result is similar with Jou's (2010) study. Affective strategies were employed the least $\left(M_{a f f}=3.26\right)$. In each different studying environment, degrees of using these variable strategies are also. They change basing on studying environment and the way to teach and study of every place.

According to Vandergrift (2003), social strategies are techniques that listeners used to collaborate with others, to verify their understanding and to lower their anxiety. In the same way, Oxford (1990) said that social strategies referred to the ways in which learners managed to interact with other learners or native speakers to facilitate their learning 
including skills such as asking questions for clarification, cooperating with peers, and developing cultural understanding. These strategies, in general, helped learners work with others to get input and practice. The findings from chapter 4 demonstrated that participants in this study applied well this kind of strategy. The results from study were consistent with Lee's (1997). His findings also indicated that strategy for asking speakers for repetition or paraphrasing to clarify comprehension was the most frequently used strategy $(M=3.80)$. The high use of social strategies may be due to the teaching objectives and curriculum design of teachers. Teachers often engage their students in learning listening skill by partnering up the students in pairs or small groups to complete learning tasks through communicative activities. These results were not consistent with Chao's (1999) research while they were used the most in the present study. The results from his project indicated that social strategies were used the least.

According to O'Malley and Chamot (1989), metacognitive strategies are a kind of self-regulated learning. It includes the attempt to plan, check, monitor, select, revise and evaluate. Vandergrift's (2003) study proved that more skilled listeners had tendency for applying metacognitive strategies to improve their listening skill. The findings of the present study showed that metacognitive strategies were applied frequently with high mean score $\left(M_{\text {meta }}=3.64\right)$. Therefore, it can be implied that participants in this study are effective listeners. And these findings were consistent with Jou's (2010) study. The results from his study indicated that metacognitive strategies were employed with mean score 3.52. However, two strategies in metacognitive strategies are thinking about my progress in learning English $(M=2.84)$ and I do not understand if I am unfamiliar with speakers' accent $(M=2.73)$ were two strategies that participants did not pay much attention among metacognitive strategies.

Cognitive strategies are related to comprehending and storing input in working memory or long-term memory for later retrieval. They are investigated from the aspects of bottom-up strategies and top-down strategies (O'Malley \& Chamot, 1989). For this kind of strategy, it was considered as the third frequently strategies used by students $\left(M_{c o g}=3.61\right)$. The findings were not consistent with Jou's (2010) research. His project showed that cognitive strategies were the highest used strategies while this one is social strategies. Although there are differences from degree of using this kind of strategies, between two studies they also exist similarity. In the present study, bottom-up strategies $(M=3.60)$ were applied more than top-down strategies $(M=3.46)$. And it is the same in Jou's (2010) study with bottom-up strategies $(M=3.76)$ used more than top-down strategies $(M=3.58)$. This means that most of students are familiar with listening for details more than they have to concentrate on main ideas. Besides, they often try to listen for each word and translate contents into Vietnamese. Therefore, they apply bottom-up strategies more than top-down strategies although both of them were applied. Especially, thinking in English instead of Vietnamese was the least used strategies $\left(M_{019}=2.95\right)$. In contrast, the study is not consistent with the findings from research of Chao (1999) when in his research the learners tended to use top-down strategies more frequently than bottom-up strategies during listening. For example, "grasp the overall meaning of the 
text" and "relate the text to what I already know about the topic", got the highest and the second frequencies (4.08 and 3.96 respectively). In short, students applied bottom-up strategies more than top-down strategies because they are English non-majored students and listening is not taught in distinct period.

Affective strategies were considered as the least used strategies among four types of strategies with mean score 3.46. Affective strategies refer to the strategies that learners use to control factors such as emotions, attitudes, motivations and values. Hence, it can be said that participants did not pay attention to this kind of strategy much as the others. The results also were consistent with the findings of Jou's (2010) study. Especially, strategy with confidence in understanding the whole contents was the least used strategy for both these studies with mean score below average scale. It might be explained that listening is not a strange skill to students because this skill was mentioned when they studied in high school. So, they will not feel worried when they are in undergraduate level. However, they do not feel confident with contents that they will listen because English is a foreign language. Understanding the contents of lectures require students to have large vocabulary and to master grammar as well as context of lectures. For above reasons, the level of their confidence in understanding the contents of lecture is not high.

In short, students used these strategies in the framework of $\mathrm{O}^{\prime}$ Malley and Chamot (1990) at different degrees. The results showed that students recognized these strategies and used already them in their language learning. However, degree of affective strategies is low. It means that students do not apply this kind of strategy effectively in their listening processing.

\subsubsection{The correlation among four types of strategies (metacognitive, cognitive, social and affective strategies)}

To answer research question three "is there any relationship among these strategies?". A Pearson correlation coefficient was computed. The result indicated that there was significant correlation between metacognitive and cognitive strategies, cognitive and social strategies, cognitive and affective strategies $(p<.000)$. This result was consistent with Zare-ee's (2003) investigation. However, the correlation between metacognitive and social strategies, metacognitive and affective strategies, social and affective strategies was not statistically significant $(p>.000)$. It may be explained that students were taught listening skill in high school, so stages such as pre-listening, while-listening and postlistening were familiar with them. They do not feel worried. For students, listening skill is important and teachers play an essential role in guiding students to gain listening skill. Hence, although the relationship between metacognitive and affective strategies as well as between metacognitive and social strategies is not significant, they still support together. For social strategies, students are spirited in asking English speakers to repeat what they said and exchange any questions they do not understand with their friends. Meanwhile, about affective strategies, students have many ways to reduce stress and worry for studying listening. Thus, two kinds of these strategies were not interactive. 
They themselves recognize the importance of listening skill and they themselves control their attitude in listening process.

\subsection{Limitations}

The present study was conducted to investigate about using listening strategies of English non-majored students and the time for carrying out this research was in period of 3 months. This was considered as limited time. Moreover, in this study, researcher collected and analyzed data by using a questionnaire. There were not tests or tasks designed to estimate the level of strategies employed by students. In addition, the number of participants was also limited. It just focused on the English non-majored students but did not examine into any particular majored ones

\subsection{Suggestions for further research}

The study was only investigated on the small group of participants. In the future, it should be extended on larger number of students. Besides, the study did not focus on one major of students. For this reason, future studies should pay attention to a group of major students such as students of medicine or students of information technology to be able to realize if there are any differences on using listening strategies among different fields. Moreover, the present study just used questionnaire to measure students' listening strategies. It should be combined with tests or tasks to evaluate the ability of using students' listening strategies for further research.

\subsection{Implications for teaching and learning strategies}

Based on the theory and the results discussed in the present study, there are some implications for teachers and learners to improve their teaching and listening learning skill in the classroom as well as in daily communication.

For teachers, to improve their students' listening ability, they need to master following teaching stages such as pre-listening, while-listening and post-listening and combine with activities in these stages to create interest for students in listening process. Besides, teachers also need to define objective and the importance of listening skill. Since then, it helps students to apply listening skill in top-down processing and bottom-up processing. Moreover, it also helps students to practice habit for thinking by English. If they listen and translate into Vietnamese at the same time, this will reduce ability of using vocabulary as well as grammar in English. For above reasons, students will feel confident when they understand the contents of texts.

There are stages that teachers need to control in teaching process. Stage one is preparation before class; stage two is classroom teaching; and stage three is learning after class. During these stages, teachers should set listening objectives, choose listening content and design listening activities. These activities are subcategories as pre-listening, while-listening and post-listening activities. In pre-listening stage, teachers should set a purpose or decide in advance of what to listen to, decide if more linguistic or background knowledge is needed. Similarly, teachers should provide opportunities for group or 
collaborative work or class discussion activities. For while-listening activities, they relate directly to engagement with the text and have some of following activities: (1) decide what is and is not important to understand, (2) use prediction or content to encourage students to monitor their comprehension when they listen, (3) use question to focus students' attention on the crucial elements of the crucial text to comprehend of the whole, (4) organize activities to guide listeners through the text. Combine activities such as getting the main ideas, topic, etc. Finally, teachers should write questions beyond the text on the board and ask students to discuss them in post-listening activities. The teachers can tell students to compare their notes and discuss what they understood in pairs or small groups or encourage students to respond to what they heard to create debate. Debating is a good way to stimulate students in communication and improve listening skill effectively.

For students, they should be more active in their learning. For example, they should usually practice English listening through English news or English songs on TV or internet to be familiar with native speakers' accent, intonation. The fact is that these participants did not have good knowledge of vocabulary and grammar. Thus, they are often afraid of listening. They should practice listening more often not only in class but also at home. There is a variety of listening texts from TV, radio, songs, news.... They can choose to be familiar with different accents, pronunciation. Besides, listening is an effective way to enhance their vocabulary, to revise grammatical structures. It is helpful for other skills such as speaking, reading and writing. Students should be encouraged to communicate with native speakers so that they can have two-way communication. It helps them be flexible and communicate better. Hence, they will not feel confused with different accents. Moreover, students should work in group or pairs to exchange information. That is a good way to increase confidence in understanding texts. Besides, they should apply studied strategies in texts frequently to improve their listening skill. For textbook of teaching, there is not any lesson for listening skill yet. So, teachers still use outside documents. For this reason, there should be a lesson plan that has enough four skills, especially listening skill to help students to be familiar with native speakers' different accents. Moreover, textbook should include many activities to support students to increase knowledge of vocabulary and grammar.

\subsection{Conclusions}

The purpose of this study is to look into listening comprehension strategies employed by English non-majored students and the relationship among these strategies. By understanding which listening strategies that students use hopes that the findings of the study will help them overcome difficulties in learning listening. Generally speaking, participants in this study employed a variety of listening comprehension strategies during the listening process and social strategies were considered as the highest used strategies among listening strategies. Furthermore, it also showed that there is a relationship and interaction between these strategies helps students to improve their listening ability effectively. However, there are some kinds of strategies that do not have 
interaction such as the relationship between metacognitive and affective strategies, between metacognitive and social strategies, between social and affective strategies. To sum up, the study has sought the answers to research questions. However, there are some limitations of the study as provided. The results cannot be generalized, so it is hoped that there will be further research conducted.

\section{Conflicts of Interest Statement}

The authors whose names are listed immediately below certify that they have NO conflicts of interest, authorship, and disclosures in publication. They confirm that this work is original and has not been published elsewhere, nor is it currently under consideration for publication elsewhere.

\section{About the Author}

Hanh Thi Dang currently is a senior lecturer at Tay Do University and has 20-year experience of teaching English; the article co-authors are Bich Van Au and Hai Thanh Chau who also experience in teaching English for so long time.

\section{References}

Barker, L., Edwards, R., Gaines, C., Gladney, K., \& Holley, F. (1980). An investigation of proportional time spent in various communication activities by college students. Journal of Applied Communication Research, 8, 101-110.

Bird, D. (1953). Teaching listening comprehension. Journal of Communication, 3, 127- 130.

Brown, J. D. (1997). Designing surveys for language programs. Eric Document Reproduction Service: ED415700.

Carrier, K., A. (2003). Improving high school English language learners' second language listening through strategy instruction. Bilingual Research Journal, 27(3), 383-408.

Chao, Y. G. (1999). EFL Listening Strategies by English Majors in Taiwan. Proceedings of the Sixteenth Conference on English Teaching and Learning in the Republic of China (pp. 465-479). Taipei, Taiwan, R.O.C. The Crane Publishing Co., Ltd.

Chamot, A. U., \& Kupper, L. (1989). Learning strategies in foreign language instruction. Foreign Language Annals, 22, 13-24.

Chang, C-S. (2008). Listening Strategies of L2 Learners with Varied Test Tasks. TESL CANADA Journal, 25(2), 1-22.

Chiu, B. E. (2006). An Investigation of English Listening Strategies Used by Continuous Education Program Students in Taiwan. Retrieved October 30, 2008 from http://web.nanya.edu.tw/tcof/tcrd/word

Chu, S. H. (2004). The Effects of Vocabulary and Question Type Instructions on Listening Comprehension of EFL Elementary School Students. Unpublished Master thesis, National Cheng Kung University, Tainan. 
Duffy, G. G. (2002). The case for direct explanation of strategies. In C. C. Block \& M. Pressley (Eds.), Comprehension instruction: Research based best practices (pp. 28-41). New York: Guilford.

Ellis, R. (1985). Understanding Second Language Acquisition. Oxford: Oxford University Press.

Ferris, D. (1998). Students' views of academic aural/oral skills: A comparative needs analysis. TESOL Quarterly, 32, 289-318.

Feyten, C. (1991). The power of listening ability: An overlooked dimension in language acquisition. Modern Language Journal, 75, 173-180.

Gilakjani, A. P \& Ahmadi, M. R. (2011). A Study of Factors Affecting EFL Learners' English Listening Comprehension and the Strategies for Improvement. Journal of Language Teaching and Research, 2 (5), 977-988.

Goh, C. C. (2002). Learners' Self-reports on Comprehension and Learning Strategies for Listening. Asian Journal of English Language Teaching, 12, 45-68.

Habte-Gabr, E. (2006). The Importance of Socio-affective Strategies in Using EFL for Teaching Mainstream Subjects. The Journal of Humanizing Language Teaching, 8(5). Retrieved September 10, 2009, from http://www.hltmag.co.uk/sep06/sart02.htm\#C1

Hamzah, M. S., Shamshiri, K., Shamshiri, K. (2009). Effects of socio-affective strategy training on listening comprehension. European Journal of Social Science, 11(4). 690697.

Hedge, T. (2005). Teaching and learning in the Language Classroom. Oxford: Oxford University Press.

Howatt, A. \& Dakin, J. (1974). Language laboratory materials, ed. J. P. B. Allen, S. P. B. Allen, and S. P. Corder (EDS). 1974, 93-102.

Jou, Y. J. (2010). A Study of English Listening Strategies Applied by Technological University Students. Unpublished master thesis, Department of Applied Foreign Languages, Cheng Shiu University.

Lee, H. M. (1997). A Study of the Listening Comprehension Strategies of Junior College EFL Listening in Taiwan. Proceedings of the Fourteenth International Symposium on English Teaching. Taipei, Taiwan, R.O.C.: The Crane Publishing Co., Ltd.

Lu, P. H. (2008). English listening comprehension strategy used by students of presessional courses of Northumbria University, Unpublished master thesis, Southern Taiwan University.

Luchini, P. L. \& Agruello, M. (2009). Listening skill teaching: some pedagogical considerations. Iranian Journal of Language Studies (IJLS), 3(3), 317-344.

Mendelsohn, D. J. (1994). Learning to listen: A strategy-based approach for the second language learner. San Diego: Dominie Press.

Morley, J. (1999). Current perspectives on improving aural comprehension. http://www.eslmag.com/MorleyAuralStory.html (26 Feb. 1999).

Murphy, J. M. (1991). Oral communication in TESOL: Integrating speaking, listening, and pronunciation. TESOL Quarterly, 25, 51-75. 
Oxford, R. (1990). Language learning strategies: What every teacher should know. Boston, MA: Heinle \& Heinle.

O’Malley, J. M., Chamot, A. U., Kupper, L. (1985). Learning strategies used by beginning and intermediate ESL students. Language Learning, 35, 21-46.

O’Malley, J. M. \& Chamot, A. U. (1989). Listening comprehension strategies in second language acquisition. Applied Linguistics, 10(4): 418-437.

Peacock, M., \& Ho, B. (2003). Student Language Learning Strategies across Eight Disciplines. International Journal of Applied Linguistics, 13, pp. 179-200.

Purdy, M. (1997). What is listening? In M. Purdy \& D. Borisoff (Eds.), Listening in everyday life: A personal and professional approach (2nd ed.) (pp. 1-20). Lanham, MD: University Press of America.

Richards, J. C. (2008). Teaching Listening and Speaking. Cambridge, England: Cambridge University Press.

Rubin, J. (1987). Learner strategies: Theoretical assumption, research history, and typology. In A. L. Wen Den \& J. Rubin (Eds.), Learner strategies in language learning (pp. 15-30). Cambridge: Prentice-Hall International.

Scarcella, R. C., \& Oxford, R. L. (1992). The tapestry of language learning: the individual in the communicative classroom. Boston, MA: Heinle \& Heinle.

Underwood, M. (1989). Teaching listening. New York: Longman.

Vandergrift, L. (1997). The comprehension strategies of second language (French) listeners: A descriptive study. Foreign Language Annals, 30(3), 387-409.

Vandergrift, L. (2003). Listening: theory and practice in modern foreign language competence. Retrieved January 4, 2009, from http://www.llas.ac.uk/resources/gpg/67.

Wills, R \& Guo, N (2006). An Investigation of Factors Influencing English Listening Comprehension and Possible Measures for Improvement. Retrieved March 12, 2011 from: http://www.aare.edu.au/05pap/guo05088.

Wolvin, A. D., \& Coakley, C. G. (1988). Listening (3rd ed.). Dubuque, IA: Wm. C. Brown. Yagang, F. (1994) Listening: Problems and solutions. In T. Kral (ed.) Teacher Development: Making the Right Moves. Washington, DC: English Language Programs Divisions, USIA.

Yan, F. (2006). Listening to the voices of pupils: An alternative route to a balanced curriculum for junior middle schools in China. Proceedings of the Asia Pacific Educational Research Association Conference, Hong Kong Nov 30th - Dec 2nd.

Zare-ee, A. (2007). The Relationship between cognitive and metacognitive strategy use and EFL Reading Achievement. Journal of Applied psychology, 2(5), 105-119. 


\section{Appendix 1: Questionnaire}

(An investigation about English listening strategies applied by English non-majored students at Tay Do University)

\section{A. Background information:}

1. Gender: male: $\square$ female: $\square$

2. Age:

3. Class:

How long have you studied English? ..years

Dear beloved friends!

This is an educational research project about the effectiveness of using English listening strategies. The table below is a series of statements about your preference for strategies used in listening process. I would like to know how far these statements match your own preference. There are not right or wrong answers. Moreover, the data I collect are for research purpose and your opinions will be respected and kept confidential. There are 30 items in the questionnaire. Please stick $(\checkmark)$ the best column that best describes your attitudes. Thank you very much for your cooperation!

\section{B. Statements for the investigation}

\begin{tabular}{|c|c|c|c|c|c|c|}
\hline Number & Items & SA & A & $\mathbf{N}$ & DA & SD \\
\hline 1 & Before listening, I prepare my mind to concentrate. & & & & & \\
\hline 2 & Before listening, I think about my progress in learning English. & & & & & \\
\hline 3 & $\begin{array}{l}\text { I clearly identify the purpose of the language activities before } \\
\text { listening. }\end{array}$ & & & & & \\
\hline 4 & I encourage myself through positive self talk. & & & & & \\
\hline 5 & I am confident in understanding the whole contents. & & & & & \\
\hline 6 & $\begin{array}{l}\text { While listening, I do not understand if I am unfamiliar with } \\
\text { speakers' accent. }\end{array}$ & & & & & \\
\hline 7 & $\begin{array}{l}\text { While listening, I while check what part of content I do not } \\
\text { understand }\end{array}$ & & & & & \\
\hline 8 & While listening, I while double check again for my answer. & & & & & \\
\hline 9 & $\begin{array}{l}\text { I am aware of my inattention and correct it while doing } \\
\text { listening test. }\end{array}$ & & & & & \\
\hline 10 & $\begin{array}{l}\text { While listening, I try to translate words or sentences into } \\
\text { Vietnamese. }\end{array}$ & & & & & \\
\hline 11 & $\begin{array}{l}\text { While listening, I will notice the information question with } \\
\text { who, whom, which, how, where... in the content. }\end{array}$ & & & & & \\
\hline 12 & While listening, I try to understand each word. & & & & & \\
\hline 13 & $\begin{array}{l}\text { While listening, I can apply the new vocabulary, phrases, or } \\
\text { grammar I have learned to understand the content. }\end{array}$ & & & & & \\
\hline 14 & $\begin{array}{l}\text { While listening, I usually repeat words or phrases softly or } \\
\text { mentally. }\end{array}$ & & & & & \\
\hline 15 & I listen for main ideas first and then details. & & & & & \\
\hline
\end{tabular}




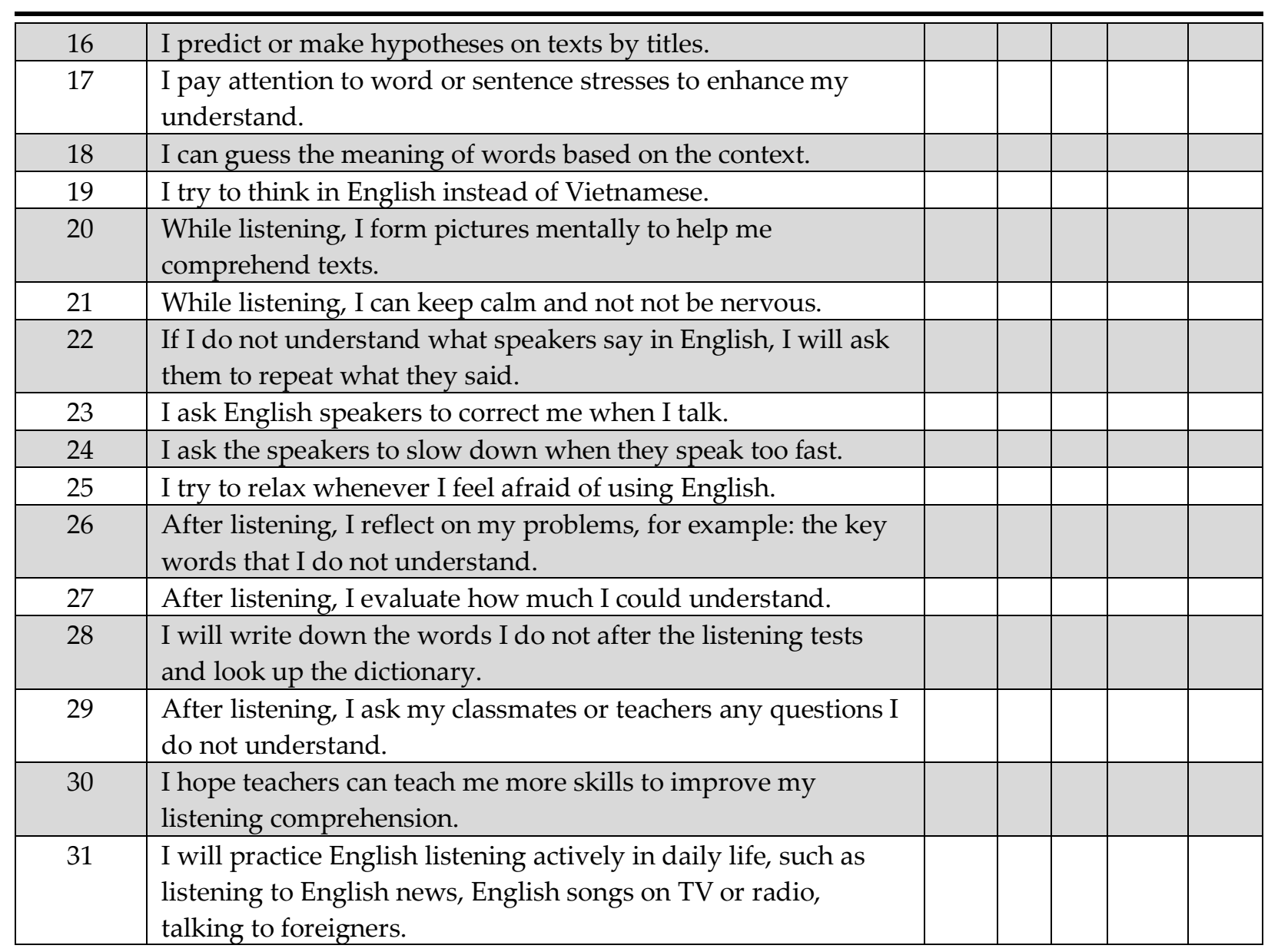

Abbreviation: $\mathrm{SA}$ = strongly agree; $\mathrm{A}$ = agree; Neutral = no opinion; $\mathrm{D}=$ disagree; $\mathrm{SD}=$ strongly disagree.

Thanks for your cooperation! 


\section{Appendix 2: Questionnaire (Piloting)}

Reliability Analysis - Scale (Alpha)

$$
\text { Mean }
$$

1. $\mathrm{C} 1$

2. $\mathrm{C} 2$

3. $\mathrm{C} 3$

4. $\mathrm{C} 4$

5. C5

6. $\mathrm{C} 6$

7. $\mathrm{C} 7$

8. $\mathrm{C} 8$

9. C9

10. $\mathrm{C} 10$

11. C11

12. $\mathrm{C} 12$

13. C13

14. C14

15. C15

16. C16

17. $\mathrm{C} 17$

18. C18

19. C19

20. C20

21. C21

22. $\mathrm{C} 22$

23. $\mathrm{C} 23$

24. C24

25. C25

26. C26

27. C27

28. C28

29. C29

30. C30

31. C31

Statistics for

SCALE
4,3750

3,1000

4,0500

3,7250

2,5250

2,6000

3,6750

3,9250

3,5500

4,0000

3,2750

3,5000

3,7750

3,8000

3,6750

3,7750

3,9250

3,3000

2,9500

3,4000

3,7750

4,1250

3,3000

4,1500

3,9500

3,7750

4,1250

3,7250

4,1750

4,3500

4,0500

Mean

114, 4000
Std Dev

Cases

0,5401

0,9001

0,6775

0,8161

0,8469

1,1048

0,9971

0,8286

1,1082

0,8771

0,8469

1,0377

1,0975

0,8829

0,9711

0,9195

0,7970

0,9392

1,0610

0,9001

0,9470

0,9920

1,1810

0,8336

0,8458

1,0250

0,6480

0,9604

0,7121

0,7355

0,9594

Variance

114, 4000
40,0

40,0

40,0

40,0

40,0

40,0

40,0

40,0

40,0

40,0

40,0

40,0

40,0

40,0

40,0

40,0

40,0

40,0

40,0

40,0

40,0

40,0

40,0

40,0

40,0

40,0

40,0

40,0

40,0

40,0

40,0

$\mathrm{N}$ of

STD Dev

10, 6958

Variables

31

Reliability Coefficients

$\mathrm{N}$ of Cases $=40,0$

$\mathrm{N}$ of Items $=31$

Alpha $=0,7993$ 


\section{Appendix 3}

Reliability Analysis - Scale (Alpha)

Mean Std Dev Cases

1. $\mathrm{C} 1$

2. $\mathrm{C} 2$

3. $\mathrm{C} 3$

4. C4

5. C5

6. C6

7. C7

8. C8

9. C9

10. C10

11. C11

12. $\mathrm{C} 12$

13. C13

14. C14

15. C15

16. C16

17. $\mathrm{C} 17$

18. C18

19. C19

20. C20

21. C21

22. C22

23. C23

24. C24

25. C25

26. C26

27. C27

28. C28

29. C29

30. C 30

31. C31

Statistics for SCALE
4,3125

2,8438

4,0938

3,6563

2,4375

2,7344

3,5625

3,8281

3,3906

3,8438

3,3281

3,5313

3,7813

3,6094

3,7969

3,7656

3,9219

3,3906

2,9531

3,3906

3,8594

4,1406

3,4688

4,1719

3,8750

3,8125

4,0781

3,7656

4,0938

4,2969

4,0000

Mean

113, 7344
Std Dev

Cases

0,5876

64,0

0,9795

64,0

0,6599

64,0

0,8012

64,0

0,8706

1,1018

64,0

64,0

0,9900

0,8272

1,0483

0,9955

0,8176

1,0833

0,9835

0,9018

0,9289

0,8115

0,7412

0,9531

1,0146

0,9363

0,8520

0,9235

1,0833

0,7465

0,8067

0,9407

0,6499

0,9214

0,6836

0,6827

0,9085

64,0

64,0

64,0

64,0

64,0

64,0

64,0

64,0

64,0

64,0

64,0

64,0

64,0

64,0

64,0

64,0

64,0

64,0

64,0

64,0

64,0

64,0

64,0

64,0

64,0

$\mathrm{N}$ of

Variance 107,7855
STD Dev 10,3820
Variables 31

Reliability Coefficients

$\mathrm{N}$ of Cases $=64,0$

$\mathrm{N}$ of Items $=31$

Alpha $=0,7985$ 
Hanh Thi Dang, Bich Van Au, Hai Thanh Chau

A STUDY OF ENGLISH LISTENING STRATEGIES APPLIED BY ENGLISH

NON-MAJORED STUDENTS AT TAY DO UNIVERSITY, VIETNAM

Creative Commons licensing terms

Authors will retain the copyright of their published articles agreeing that a Creative Commons Attribution 4.0 International License (CC BY 4.0) terms will be applied to their work. Under the terms of this license, no permission is required from the author(s) or publisher for members of the community to copy, distribute, transmit or adapt the article content, providing a proper, prominent and unambiguous attribution to the authors in a manner that makes clear that the materials are being reused under permission of a Creative Commons License. Views, opinions, and conclusions expressed in this research article are views, opinions and conclusions of the author(s). Open Access Publishing Group and European Journal of English Language Teaching shall not be responsible or answerable for any loss, damage or liability caused in relation to/arising out of conflict of interests, copyright violations and inappropriate or inaccurate use of any kind content related or integrated on the research work. All the published works are meeting the Open Access Publishing requirements and can be freely accessed, shared, modified, distributed and used in educational, commercial and non-commercial purposes under a Creative Commons Attribution 4.0 International License (CC BY 4.0). 